\title{
Room temperature stable multitalent: highly reactive and versatile copper guanidine complexes in oxygenation reactions
}

\author{
Melanie Paul $^{1} \cdot$ Alexander Hoffmann $^{1}$ (D) . Sonja Herres-Pawlis ${ }^{1}$ (D)
}

Received: 5 November 2020 / Accepted: 20 January 2021 / Published online: 17 February 2021

(c) The Author(s) 2021

\begin{abstract}
Inspired by the efficiency of natural enzymes in organic transformation reactions, the development of synthetic catalysts for oxygenation and oxidation reactions under mild conditions still remains challenging. Tyrosinases serve as archetype when it comes to hydroxylation reactions involving molecular oxygen. We herein present new copper(I) guanidine halide complexes, capable of the activation of molecular oxygen at room temperature. The formation of the reactive bis( $\mu$-oxido) dicopper(III) species and the influence of the anion are investigated by UV/Vis spectroscopy, mass spectrometry, and density functional theory. We highlight the catalytic hydroxylation activity towards diverse polycyclic aromatic alcohols under mild reaction conditions. The selective formation of reactive quinones provides a promising tool to design phenazine derivatives for medical applications.
\end{abstract}

\section{Graphic abstract}

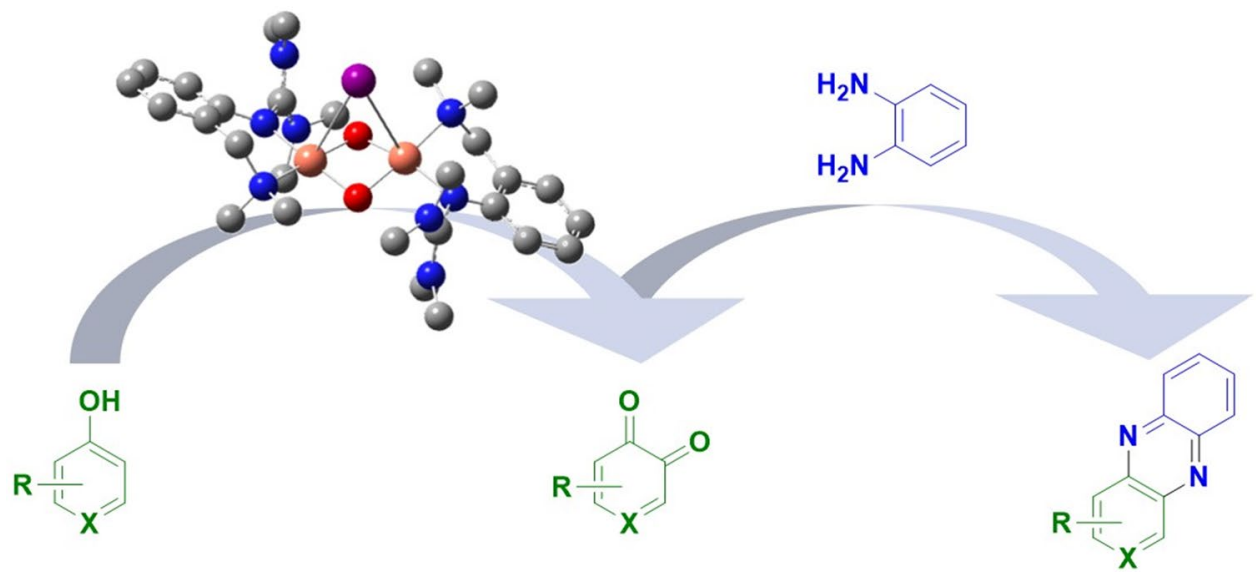

Keywords Copper catalysis $\cdot$ Dioxygen activation $\cdot$ Guanidine $\cdot$ Phenazine $\cdot$ Tyrosinase

\section{Introduction}

Designing environmentally friendly, selective and efficient oxidation catalysts is one major goal in chemical research [1-3]. Copper-based enzymes demonstrated impressively

Sonja Herres-Pawlis

sonja.herres-pawlis@ac.rwth-aachen.de

https://www.bioac.ac.rwth-aachen.de/

1 Institute of Inorganic Chemistry, RWTH Aachen University, Landoltweg 1, 52074 Aachen, Germany their ability to activate molecular oxygen, forming catalytically active copper-dioxygen species [4-6]. The type III copper enzyme tyrosinase binds molecular oxygen between two copper centers in a side-on peroxido motif. Tyrosinase catalyzes the ortho-hydroxylation of L-tyrosine to L-Dopa as well as the subsequent oxidation to L-Dopaquinone in melanin biosynthesis [7-9].

Bioinorganic chemistry provided a deep insight into the molecular mechanisms of copper-based enzymes by developing synthetic model systems with tailored oxygenation 
and oxidation abilities. Over the last years, such smallmolecule systems mimicking the active site and functionality of tyrosinase were studied by many research groups [ 5 , $10,11]$. Surprisingly, only a few examples of catalytically active model systems have been reported until now. In 1990, Réglier and co-workers developed the first model system $\left[\mathrm{Cu}_{2}(\mathrm{MeCN})_{4}\left(\mathrm{BiPh}(\mathrm{impy})_{2}\right]\left(\mathrm{PF}_{6}\right)_{2}\right.$, catalyzing the oxygenation reaction of 2,4-di-tert-butyl phenol to 3,5-di-tert-butyl quinone [12]. Since then, further systems were reported by the working groups of Casella [13], Lumb and Ottenwaelder [14-16], Tuczek [17-24] and Herres-Pawlis [25-29], demonstrating that very different supporting ligand systems feature catalytic transformations of phenolic substrates (Fig. 1).

Among these $\mathrm{N}$-donor ligands, which frequently consist of pyridinyl, pyrazolyl, imine or amine units, guanidines represent strong $\mathrm{N}$-donor ligands due to their high basicity. Guanidines are known to stabilize reactive bis( $\mu$-oxido) dicopper(III) cores and even superoxido species [30-39]. Recently, we have shown that a moderate stability of hybrid guanidine-stabilized bis( $\mu$-oxido) species at low temperatures in the presence of weakly coordinating anions is accompanied by a high tyrosinase-like activity in oxygenation reactions of a large number of phenolic substrates [40].
The reported quinones were found to form exclusively bent phenazines, as predicted by density functional theory (DFT) calculations using the Fukui function. Synthetic access to phenazine derivatives is of major interest, as they feature antibacterial, antitumor, and antimalarial reactivities [41-48].

Herein, we report the synthesis of three novel copper(I) complexes, stabilized by the hybrid guanidine ligand 2-\{2-((dimethylamino)methyl)phenyl $\}-1,1,3,3$-tetramethylguanidine (TMGbenza, L1), and its activity in activation and transfer reactions of molecular oxygen. We focus on the present anion dependency regarding the stability of the formed bis( $\mu$-oxido) complex, enabling the catalytic oxygenation of polycyclic aromatic alcohols and subsequent condensation of the resulting quinones into phenazines in a one-pot reaction under mild conditions.

\section{Materials and methods}

\section{General remarks}

All synthetic procedures were performed under an inert atmosphere of nitrogen with the use of standard Schlenk or
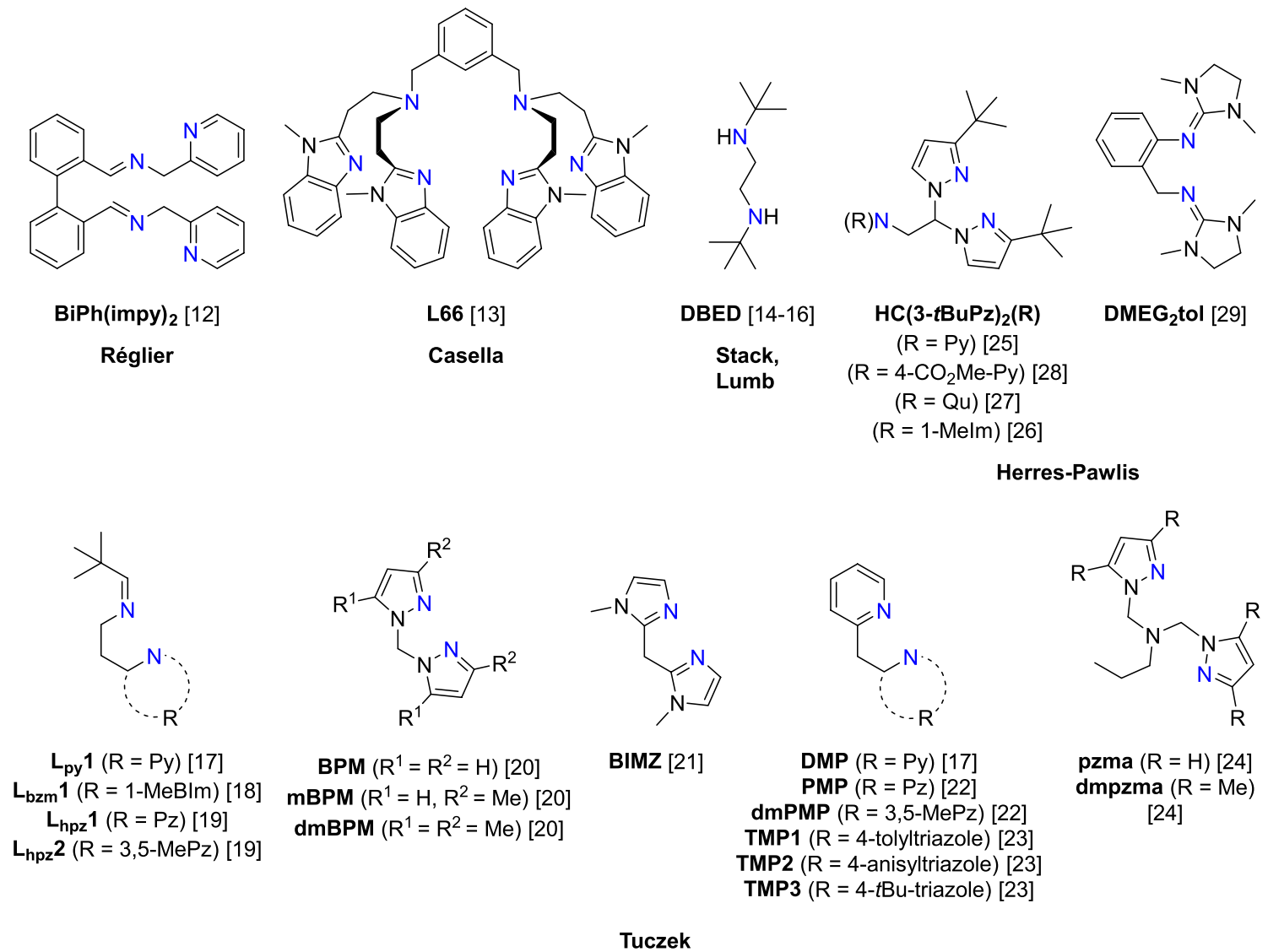

Fig. 1 Ligand design in synthetic model systems capable of tyrosinase-like oxygenation reactions [5, 10-29] 
glovebox techniques. All chemicals were purchased commercially (Table S1 in the Supporting Information) and used without further purification unless otherwise noted. Solvents were purified under nitrogen atmosphere via distillation from $\mathrm{CaH}_{2}$ or sodium/benzophenone ketyl radical. Some copper salts [49, 50] and hybrid guanidine ligand TMGbenza [40] were synthesized according to literature procedures. Triethylamine was purified by distillation from $\mathrm{CaH}_{2}$. Molecular sieves ( $3 \AA$, AppliChem) were flame-dried prior to use. Thin-layer chromatography sheets were purchased from MACHEREY-NAGEL $\left(\mathrm{SiO}_{2}\right.$, layer thickness $0.20 \mathrm{~mm}$, fluorescent indicator). Column chromatography was performed on Geduran Si 60 (40-63 $\mu \mathrm{m}$, Merck).

\section{Instruments}

${ }^{1} \mathrm{H}$ and ${ }^{13} \mathrm{C}\left\{{ }^{1} \mathrm{H}\right\}$ NMR spectra were recorded on a Bruker Avance II 400 and Bruker Avance III HD 400 spectrometer at $25^{\circ} \mathrm{C}$ in NMR tubes, respectively. Resonances were referenced to the residual solvent signal, relative to TMS. Chemical shifts were assigned with the use of two-dimensional NMR experiments (COSY, HSQC, HMBC). DOSY NMR measurements were performed using ${ }^{1} \mathrm{H}$ NMR standard processing applied on pseudo-2D datasets $(\mathrm{si}=8 \mathrm{k}, \mathrm{lb}=0.3$, $\mathrm{xf} 2$, abs2). Self-diffusion constants were evaluated by using Dynamics Center. Integration areas were defined manually according to the proton shifts, and its diffusion constants were arithmetically averaged. All NMR data were deposited as original data in Chemotion Repository and are published under an Open Access model. The link to the original data is given in the analytical description.

Elemental analyses were carried out on an elementar vario EL and an elementar vario EL cube instrument.

ESI mass spectra were recorded on a Thermo Fisher Scientific LTQ Orbitrap XL spectrometer at a source voltage of $4.49 \mathrm{kV}$ and a capillary temperature of $299.54{ }^{\circ} \mathrm{C}$.

Cryospray-ionization mass spectrometry (CSI-MS) measurements were performed on an UHR-TOF Bruker Daltonik maXis II, an ESI-quadrupole time-of-flight (qToF) mass spectrometer capable of a resolution of at least 80.000 FWHM, which was coupled to a Bruker Daltonik Cryospray unit. Detection was either in the positive or in the negative ion mode; the source voltage was $3.5 \mathrm{kV}$. The drying gas $\left(\mathrm{N}_{2}\right)$, to achieve solvent removal, and the spray gas were both held at $-80^{\circ} \mathrm{C}$. The mass spectrometer was calibrated subsequently to every experiment via direct infusion of a L-proline sodium salt solution, which provided a $\mathrm{m} / \mathrm{z}$ range of singly charged peaks up to $3000 \mathrm{Da}$ in both ion modes.

FT-IR spectra were recorded on a Shimadzu IR Tracer 100 equipped with a CsI beam splitter in combination with an ATR unit (Quest model from Specac utilizing a robust monolithic crystalline diamond) in a resolution of $2 \mathrm{~cm}^{-1}$ and on a ThermoFisher Avatar ${ }^{\mathrm{TM}} 360$ spectrometer with the use of $\mathrm{KBr}$ pellets or $\mathrm{NaCl}$ plates in a resolution of $2 \mathrm{~cm}^{-1}$.

UV/Vis spectroscopic measurements were carried out on a Cary 60 spectrophotometer of Agilent Technologies connected via a Cary 50 fiber optic coupler and combined with a fiber-optic quartz glass immersion probe (Hellma, $1 \mathrm{~mm}$ ) and a tailored Schlenk cell.

The single-crystal diffraction data for C1a-C3a are presented in Table S2 in the Supporting Information. The data for C1a-C3a were collected on a Stadivari diffractometer of Stoe with an Eulerian cradle and Dectris Pilatus3 R $200 \mathrm{~K}$ hybrid pixel detector with GeniX 3D high flux Mo-K $\alpha$ radiation $(0.71073 \AA)$ at $100 \mathrm{~K}$. The temperature was controlled by using an Oxford Cryostream 800. Crystals were mounted with grease on glass fibers. Data were collected with X-Area Pilatus and integrated with X-Area Integrate and X-Area Recipe. The absorption correction was performed by Gaussian integration with X-Red32. Scaling of reflections was carried out by using X-Area LANA [51-54].

The structures were solved by direct and conventional Fourier methods and all non-hydrogen atoms were refined anisotropically with full-matrix least-squares based on $\mathrm{F}^{2}$ (XPREP [55], SHELXT [56], SHELXL [57] and ShelXle [58]). Hydrogen atoms were derived from difference Fourier maps and placed at idealized positions, riding on their parent $\mathrm{C}$ atoms, with isotropic displacement parameters $\mathrm{U}_{\mathrm{iso}}(\mathrm{H})=1.2 \mathrm{U}_{\mathrm{eq}}(\mathrm{C})$ and $1.5 \mathrm{U}_{\mathrm{eq}}(\mathrm{C}$ methyl). All methyl groups were allowed to rotate but not to tip.

Full crystallographic data have been deposited with the Cambridge Crystallographic Data Centre as supplementary no. CCDC-2003620 for C1a, CCDC-2003621 for C2a and CCDC-2003622 for C3a. Copies of the data can be obtained free of charge on application to CCDC, 12 Union Road, Cambridge CB2 1EZ, UK (fax: (+44)1223-336-033; e-mail: deposit@ccdc.cam.ac.uk).

\section{Computational details}

Density functional theory (DFT) calculations were performed by using Gaussian 16, Revision B.01 [59]. The geometry optimizations were started based on the geometry of the solid-state structures, using the TPSSh functional [60-62] and the Ahlrichs type basis set def2-TZVP [63-66] as implemented in Gaussian 16, Revision B.01 [59]. For the heavier atom I, effective core potentials (ECP) were used, which were obtained from the TURBOMOLE basis set 
library [67, 68]. Polarizable Continuum Model (PCM) was utilized as solvent model implemented in Gaussian 16, Revision B.01. The D3 dispersion with Becke-Johnson damping was applied for empirical dispersion correction, which is implemented in Gaussian 16, Revision B.01 [69-72].

\section{Synthetic procedures}

\section{Synthesis of $[\mathrm{Cu}(\mathrm{L} 1) \mathrm{X}](\mathrm{X}=\mathrm{I}, \mathrm{Br}, \mathrm{Cl})$}

A solution of TMGbenza (L1) $(24.8 \mathrm{mg}, 0.10 \mathrm{mmol}, 1.0 \mathrm{eq})$ in dried acetonitrile $(2.0 \mathrm{~mL})$ was added dropwise to a stirring suspension of $\mathrm{CuX}(0.10 \mathrm{mmol}, 1.0 \mathrm{eq})$ in dried acetonitrile $(3.0 \mathrm{~mL})$ during a period of $10 \mathrm{~min}$. The resulting solution was stirred for $15 \mathrm{~min}$ and evaporated to dryness (Caution! The complex is very sensitive to oxygen which is indicated by the partial coloration of the precipitate or oil to light green). The residue was washed with dried diethyl ether $(3 \times 1.0 \mathrm{~mL})$, with dried pentane $(3 \times 1.0 \mathrm{~mL})$ and dried in vacuo. Single crystals suitable for X-ray diffraction were grown by slow diffusion of diethyl ether into the acetonitrile solution.

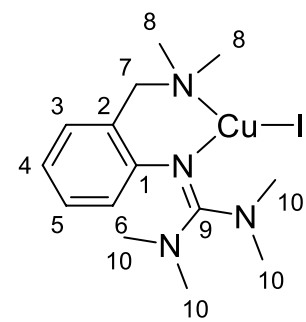

[Cu(L1)I] (C1a): The title compound was isolated as a colorless solid (43 mg, $99 \mu \mathrm{mol}, 99 \%) .{ }^{1} \mathbf{H}$ NMR (400 MHz, Acetonitrile- $\left.d_{3}, 25^{\circ} \mathrm{C}\right): \delta[\mathrm{ppm}]=7.23(\mathrm{ddd}, J=7.8,7.4$, $1.7 \mathrm{~Hz}, 1 \mathrm{H}, \mathrm{H6}$ ), 7.19-7.16 (m, 1H, H4), 6.92 (td, $J=7.4$, $1.3 \mathrm{~Hz}, 1 \mathrm{H}, \mathrm{H} 5), 6.47$ (dd, $J=7.9,1.3 \mathrm{~Hz}, 1 \mathrm{H}, \mathrm{H} 3), 3.55$ (s, 2H, H7), 2.77 (s, 12H, H10), 2.27 (s, 6H, H8). ${ }^{13} \mathbf{C}\left\{{ }^{1} \mathbf{H}\right\}$ NMR $\left(101 \mathrm{MHz}\right.$, Acetonitrile- $\left.d_{3}, 25{ }^{\circ} \mathrm{C}\right): \delta[\mathrm{ppm}]=165.0$ (C9), 151.2 (C1), 132.9 (C4), 130.1 (C6), 129.0 (C2), 123.2 (C3), 122.1 (C5), 64.3 (C7), 47.6 (C8), 40.7 (C10). CHN anal. calc. for $\mathrm{C}_{14} \mathrm{H}_{24} \mathrm{CuIN}_{4}$ : $\mathrm{C}, 38.32 \% ; \mathrm{H}, 5.51 \%$; , 12.77\%; found: C, $38.25 \%$; H, 5.32\%; N, $12.71 \%$. HRMS$\mathbf{E S I}+(\mathbf{M e C N}): \mathrm{m} / \mathrm{z}$ calc. for $\left[\left(\mathrm{C}_{14} \mathrm{H}_{24} \mathrm{~N}_{4}\right) \mathrm{Cu}\right]^{+}: 311.1297$, found: 311.1292. IR (KBr): $\widetilde{\mathrm{v}}\left[\mathrm{cm}^{-1}\right]=3007$ (w, C-H $\left.\mathrm{H}_{\text {arom }}\right)$, 2975 (w, C-H arom $\left._{1}\right), 2943$ (m, C-H $\left.\mathrm{H}_{\text {arom }}\right), 2865$ (m, C-H aliph), 2829 (m, C-H aliph $\left._{1}\right), 2797$ (m, C-H aliph), 2722 (w), 1594 (m, $\mathrm{C}=\mathrm{N}), 1542$ (s), 1522 (vs), 1481 (s), 1463 (s), 1449 (m), 1419 (s), $1406(\mathrm{~s}), 1392(\mathrm{~s}), 1372(\mathrm{~m}), 1330(\mathrm{~m}), 1267(\mathrm{~m})$, $1250(\mathrm{~m}), 1230(\mathrm{~m}), 1208(\mathrm{~m}), 1191(\mathrm{~m}), 1175(\mathrm{~m}), 1154$ (m), $1110(\mathrm{~m}), 1062(\mathrm{~m}), 1029(\mathrm{~m}), 1002(\mathrm{~m}), 945(\mathrm{w})$, 925 (w), 868 (m), $841(\mathrm{~m}), 832(\mathrm{~m}), 789(\mathrm{~m}), 758(\mathrm{~m}), 730$ (m), $695(\mathrm{~m}), 627$ (m). Additional information on the NMR spectra of the target compound C1a including original data files is available via Chemotion Repository: https://dx.doi. org/10.14272/DTVVDHUKUBSTJW-UHFFFAOYSA-M.1

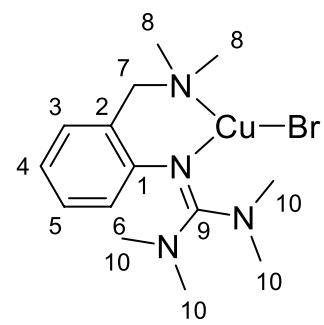

[Cu(L1)Br] (C2a): The title compound was isolated as a colorless solid (38 mg, $97 \mu \mathrm{mol}, 97 \%) .{ }^{1} \mathbf{H}$ NMR (400 MHz, Acetonitrile- $\left.d_{3}, 25^{\circ} \mathrm{C}\right): \delta[\mathrm{ppm}]=7.21-7.17(\mathrm{~m}, 1 \mathrm{H}, \mathrm{H} 6)$, $7.13(\mathrm{td}, J=7.7,1.6 \mathrm{~Hz}, 1 \mathrm{H}, \mathrm{H} 4), 6.86(\mathrm{td}, J=7.4,1.2 \mathrm{~Hz}$, $1 \mathrm{H}, \mathrm{H} 5), 6.44$ (dd, $J=8.0,1.1 \mathrm{~Hz}, 1 \mathrm{H}, \mathrm{H} 3), 3.42(\mathrm{~s}, 2 \mathrm{H}$, H7), 2.69 (s, 12H, H10), 2.20 (s, 6H, H8). ${ }^{13} \mathbf{C}\left\{{ }^{1} \mathbf{H}\right\}$ NMR (101 MHz, Acetonitrile- $\left.d_{3}, 25{ }^{\circ} \mathrm{C}\right): \delta[\mathrm{ppm}]=164.9$ (C9), 151.2 (C1), 132.7 (C6), 129.9 (C2), 129.1 (C4), 123.2 (C3), 122.2 (C5), 64.2 (C7), 46.9 (C8), 40.4 (C10). CHN anal. calc. for $\mathrm{C}_{14} \mathrm{H}_{24} \mathrm{CuBrN}_{4}$ : C $42.92 \%$; $\mathrm{H} 6.17 \%$; $\mathrm{N}$ 14.30\%; found: $\mathrm{C} 42.81 \%$; $\mathrm{H}$ 6.02\%; $\mathrm{N} 14.27 \%$. HRMS$\mathbf{E S I}+(\mathbf{M e C N}): \mathrm{m} / \mathrm{z}$ calc. for $\left[\left(\mathrm{C}_{14} \mathrm{H}_{24} \mathrm{~N}_{4}\right) \mathrm{Cu}\right]^{+}: 311.1297$, found: 311.1293. IR $(\mathbf{K B r}): \tilde{v}\left[\mathrm{~cm}^{-1}\right]=2961\left(\mathrm{w}, \mathrm{C}-\mathrm{H}_{\text {arom }}\right)$, 2924 (m, C- $\mathrm{H}_{\text {arom }}$ ), 2852 (w, C-H aliph), $1543(\mathrm{~m}, \mathrm{C}=\mathrm{N})$, $1518(\mathrm{~s}), 1481(\mathrm{~m}), 1420(\mathrm{~m}), 1406(\mathrm{~m}), 1391(\mathrm{~m}), 1373(\mathrm{~m})$, 1331 (w), 1261 (m), 1230 (vw), 1154 (m), 1097 (m), 1065 (m), $1029(\mathrm{~s}), 1006(\mathrm{~s}), 870(\mathrm{~m}), 842(\mathrm{~m}), 789(\mathrm{vs}), 756(\mathrm{~s})$, $730(\mathrm{~m}), 694(\mathrm{~m}), 630$ (vw), $554(\mathrm{w}), 484(\mathrm{~m})$. Additional information on the NMR spectra of the target compound C2a including original data files is available via Chemotion Repository: https://dx.doi.org/10.14272/XYBUOSNKFW KMII-UHFFFAOYSA-M.1

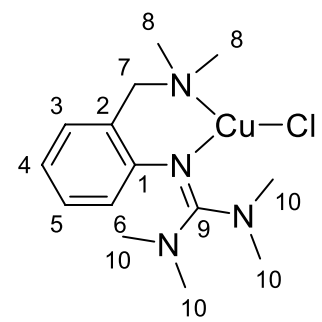

[Cu(L1)Cl] (C3a): The title compound was isolated as a colorless solid (33 mg, $95 \mu \mathrm{mol}, 95 \%)$. ${ }^{\mathbf{1}} \mathbf{H}$ NMR $(400 \mathrm{MHz}$, Acetonitrile- $\left.d_{3}, 25{ }^{\circ} \mathrm{C}\right): \delta[\mathrm{ppm}]=7.22-7.12(\mathrm{~m}, 2 \mathrm{H}$, $\mathrm{H} 4+\mathrm{H} 6), 6.94-6.85$ (m, 1H, H5), 6.44 (d, $J=7.8 \mathrm{~Hz}, 1 \mathrm{H}$, H3), 3.48 (s, 2H, H7), 2.74 (s, 12H, H10), 2.24 (s, 6H, H8). ${ }^{13} \mathbf{C}\left\{{ }^{1} \mathbf{H}\right\}$ NMR $\left(101 \mathrm{MHz}\right.$, Acetonitrile- $\left.d_{3}, 25{ }^{\circ} \mathrm{C}\right): \delta$ $[\mathrm{ppm}]=164.1$ (C9), 151.1 (C1), 132.3 (C6), 129.7 (C2), 
129.6 (C4), 123.3 (C3), 122.0 (C5), 63.4 (C7), 46.4 (C8), 40.2 (C10). $\mathbf{C H N}$ anal. calc. for $\mathrm{C}_{14} \mathrm{H}_{24} \mathrm{CuClN}_{4}$ : $\mathrm{C} 48.41 \%$; H $6.96 \%$; N $16.13 \%$; found: C $48.30 \%$; H $6.89 \%$; N $15.98 \%$. HRMS-ESI + (MeCN): m/z calc. for $\left[\left(\mathrm{C}_{14} \mathrm{H}_{24} \mathrm{~N}_{4}\right) \mathrm{Cu}\right]^{+}$: 311.1297, found: 311.1295. IR (KBr): $\tilde{\mathrm{v}}\left[\mathrm{cm}^{-1}\right]=2961(\mathrm{~m}$, C- $\mathrm{H}_{\text {arom }}$ ), 2922 (m, C-H arom $), 2853$ (m, C-H aliph $), 2811$ (w, C- aliph $_{\text {) }} 1538(\mathrm{~m}, \mathrm{C}=\mathrm{N}), 1530(\mathrm{~m}), 1483(\mathrm{w}), 1417$ (m), 1401 (m), 1393 (m), 1370 (w), 1335 (vw), 1259 (m), 1232 (vw), 1149 (w), 1098 (m), 1062 (m), 1028 (s), 1005 (s), 869 (m), 843 (m), 791 (vs), 757 (s), 734 (vw), 700 (vw), 553 (vw), 476 (vw), 458 (vw). Additional information on the NMR spectra of the target compound C3a including original data files is available via Chemotion Repository: https ://dx.doi.org/10.14272/DHTDCYWQWFEGRN-UHFFF AOYSA-M.1

\section{Synthesis of $\left[\mathrm{Cu}_{2}(\mu-0)_{2}(\mathrm{~L} 1)_{2}\right] \mathrm{X}_{2}\left([01] \mathrm{X}_{2}\right)$}

Dried and degassed tetrahydrofuran $(9.5 \mathrm{~mL})$ was saturated with dioxygen at the respective temperature. The copper(I) complex $(0.010 \mathrm{mmol}, 2.0 \mathrm{eq})$ in acetonitrile $(0.5 \mathrm{~mL})$ was prepared under inert conditions and added rapidly via a Hamilton syringe. The formation of the bis( $\mu$-oxido) species was followed by UV/Vis spectroscopy.

\section{Titration of [01I] $]^{+}$with Copper Salt Cul}

Complex C1a was oxygenated to give $[\mathbf{O 1 I}]^{+}(0.5 \mathrm{mM}$, $1.0 \mathrm{eq}$ ) as described above. Excess of $\mathrm{O}_{2}$ was removed by three cycles of evacuation and purging with $\mathrm{N}_{2}$. A tenfold stock solution of $\mathrm{CuI}(9.5 \mathrm{mg}, 50.0 \mu \mathrm{mol}, 10.0 \mathrm{eq})$ in acetonitrile $(1.0 \mathrm{~mL})$ was prepared and one-tenth of it positioned in a Hamilton syringe. The titrant was added stepwise in $0.1 \mathrm{~mL}$ (1.0 eq) steps. The titration experiment was followed by UV/Vis spectroscopy. After stabilization of the optical spectrum, the next aliquot of $\mathrm{CuI}$ was injected.

\section{Salt Metathesis of $[01]\left(\mathrm{PF}_{6}\right)_{2}$ with $\mathrm{Bu}_{4} \mathrm{NX}(\mathrm{X}=\mathrm{I}, \mathrm{Br}, \mathrm{Cl})$}

[O1] $\left(\mathrm{PF}_{6}\right)_{2}$ in tetrahydrofuran $(0.5 \mathrm{mM}, 1.0 \mathrm{eq})$ was synthesized according to our previously reported protocol [40]. Excess of $\mathrm{O}_{2}$ was removed by three cycles of evacuation and purging with $\mathrm{N}_{2}$. A tenfold stock solution of $\mathrm{Bu}_{4} \mathrm{NX}(50.0 \mu \mathrm{mol}, 10.0 \mathrm{eq})$ in acetonitrile $(1.0 \mathrm{~mL})$ was prepared and one-tenth of it positioned in a Hamilton syringe. The titrant was added stepwise in $0.1 \mathrm{~mL}$ (1.0 eq) steps. The titration experiment was followed by UV/Vis spectroscopy. After stabilization of the optical spectrum, the next aliquot of $\mathrm{Bu}_{4} \mathrm{NX}$ was injected.
Competitive oxygenation of $\mathrm{C} 1 \mathrm{a}$ and [ $\mathrm{Cu}(\mathrm{L} 1)(\mathrm{MeCN})]$ $\mathrm{PF}_{6}$

Dried and degassed tetrahydrofuran $(9.5 \mathrm{~mL})$ was saturated with molecular oxygen at $-90{ }^{\circ} \mathrm{C}$. The colorless precursor complexes C1a (0.005 mmol, $2.0 \mathrm{eq})$ and $[\mathrm{Cu}(\mathbf{L 1})(\mathrm{MeCN})]$ $\mathrm{PF}_{6}$ [40] $(0.005 \mathrm{mmol}, 2.0 \mathrm{eq})$ each in acetonitrile $(0.25 \mathrm{~mL})$ were prepared under inert conditions and added simultaneously via a Hamilton syringe. The competitive oxygenation of $\mathbf{C 1 a}$ and $[\mathrm{Cu}(\mathbf{L 1})(\mathrm{MeCN})] \mathrm{PF}_{6}$ was followed by UV/Vis spectroscopy.

\section{Catalytic oxygenation reactions of phenolic substrates}

Flame-dried molecular sieves (400 mg, 3 A) were placed in a flask. Dried and degassed tetrahydrofuran $(18 \mathrm{~mL})$ was saturated with molecular oxygen at room temperature. The colorless precursor complex C1a or C1a.CuI $(0.10 \mathrm{mmol}$, $2 \mathrm{eq})$ in acetonitrile ( $2 \mathrm{~mL}$ ) was added rapidly via a Hamilton syringe and the bis( $\mu$-oxido) complex $[\mathbf{O 1 I}]\left(\mathrm{CuI}_{2}\right)$ was formed within two hours. The substrate solution was prepared by dissolving the substrate (1.25 mmol, $25 \mathrm{eq})$ in dried solvent (tetrahydrofuran or methanol) and subsequent adding of triethylamine $(0.35 \mathrm{~mL}, 2.50 \mathrm{mmol}$, $50 \mathrm{eq})$. The solution was injected in one portion into the reaction mixture and stirred at room temperature for at least three hours. 1,2-Phenylenediamine solution (270.3 mg, $2.50 \mathrm{mmol}, 50 \mathrm{eq}$ ) was prepared by dissolving it in dried tetrahydrofuran $(2 \mathrm{~mL})$ and then added to the reaction mixture. After stirring overnight at room temperature, the reaction was quenched by using hydrochloric acid (0.5 M, $50 \mathrm{~mL}$ ) and EDTA (one spatula). The organic solvents were removed under reduced pressure. The aqueous phase was extracted with methylene chloride $(4 \times 100 \mathrm{~mL})$. The combined organic layers were dried over $\mathrm{Na}_{2} \mathrm{SO}_{4}$ and evaporated to dryness. The crude product was purified via column chromatography and/or by sublimation. The product was analyzed by NMR spectroscopy.

\section{Benzo[a]phenazine (P1) $[40,73]$}

The title compound was purified by column chromatography $\left(\mathbf{R}_{\mathbf{f}}=0.64\right.$; ethyl acetate/n-hexane 15:85) as well as by sublimation and isolated as a yellow solid (121 mg, $0.525 \mathrm{mmol}, 42 \%)$. ${ }^{1} \mathbf{H}$ NMR (400 MHz, DMSO- $d_{6}$, $\left.25{ }^{\circ} \mathrm{C}\right): \delta[\mathrm{ppm}]=9.29-9.23(\mathrm{~m}, 1 \mathrm{H}), 8.38-8.31(\mathrm{~m}, 1 \mathrm{H})$, 8.30-8.25 (m, 1H), $8.20(\mathrm{~d}, J=9.3 \mathrm{~Hz}, 1 \mathrm{H}), 8.11-8.06(\mathrm{~m}$, 1H), 8.02-7.93 (m, 3H), 7.90-7.82 (m, 2H). ${ }^{13} \mathbf{C}\left\{{ }^{1} \mathbf{H}\right\}$ NMR $\left(101 \mathrm{MHz}, \mathrm{DMSO}-d_{6}, 25^{\circ} \mathrm{C}\right): \delta[\mathrm{ppm}]=143.1,142.2$, $141.7,141.1,133.4,132.9,130.5,130.5,130.2,130.1$, $129.2,128.9,128.5,128.1,126.8,124.6$. 


\section{Quinolino[3,4-b]quinoxaline (P2) [40]}

The title compound was purified by column chromatography $\left(\mathbf{R}_{\mathbf{f}}=0.46\right.$; ethyl acetate/n-hexane 20:80) and isolated as a yellow solid (162 mg, $0.700 \mathrm{mmol}, 56 \%) .{ }^{1} \mathbf{H}$ NMR $\left(400 \mathrm{MHz}, \mathrm{DMSO}-d_{6} ; 25^{\circ} \mathrm{C}\right): \delta[\mathrm{ppm}]=9.60(\mathrm{~s}, 1 \mathrm{H}), 9.16$ (ddd, $J=8.0,1.6,0.6 \mathrm{~Hz}, 1 \mathrm{H}), 8.44-8.40(\mathrm{~m}, 2 \mathrm{H}), 8.26-8.19$ (m, 1H), 8.17-8.06 (m, 2H), 8.01 (ddd, $J=8.1,7.2,1.6 \mathrm{~Hz}$, 1H), 7.94-7.89 (m, 1H). ${ }^{\mathbf{1 3}} \mathbf{C}\left\{{ }^{1} \mathbf{H}\right\}$ NMR (101 MHz, DMSO$\left.d_{6}, 25^{\circ} \mathrm{C}\right): \delta[\mathrm{ppm}]=155.5,145.0,143.8,142.9,142.2$, $136.6,133.0,131.7,131.5,129.9,129.7,129.3,128.6$, 124.0, 123.9.

\section{Pyrido[3,2-a]phenazine (P3) [40]}

The title compound was purified by column chromatography $\left(\mathbf{R}_{\mathbf{f}}=0.27\right.$; ethyl acetate/n-hexane $\left.20: 80\right)$ and isolated as a yellow solid (177 mg, $0.765 \mathrm{mmol}, 61 \%) .{ }^{1} \mathbf{H}$ NMR $\left(400 \mathrm{MHz}, \mathrm{DMSO}-d_{6}, 25^{\circ} \mathrm{C}\right): \delta[\mathrm{ppm}]=9.51(\mathrm{dd}, J=8.2$, $1.7 \mathrm{~Hz}, 1 \mathrm{H}), 9.12$ (dd, $J=4.5,1.7 \mathrm{~Hz}, 1 \mathrm{H}), 8.39-8.29$ (m, $2 \mathrm{H}), 8.23(\mathrm{~s}, 2 \mathrm{H}), 8.05-8.00(\mathrm{~m}, 2 \mathrm{H}), 7.86(\mathrm{dd}, J=8.2$, $4.5 \mathrm{~Hz}, 1 \mathrm{H}) .{ }^{13} \mathbf{C}\left\{{ }^{1} \mathbf{H}\right\}$ NMR $\left(101 \mathrm{MHz}, \mathrm{DMSO}-d_{6}, 25^{\circ} \mathrm{C}\right)$ : $\delta[\mathrm{ppm}]=152.3,149.3,142.5,142.5,141.3,140.9,134.2$, $132.5,131.2,131.1,130.8,129.3,129.2,126.0,123.1$.

\section{Pyrrolo[3,2-a]phenazine (P4) [40]}

The title compound was purified by column chromatography $\left(\mathbf{R}_{\mathbf{f}}=0.60\right.$; ethyl acetate/n-hexane $\left.75: 25\right)$ and isolated as a yellow solid $(112 \mathrm{mg}, 0.511 \mathrm{mmol}, 41 \%)$. ${ }^{1} \mathbf{H}$ NMR $\left(400 \mathrm{MHz}, \mathrm{DMSO}-d_{6}, 25^{\circ} \mathrm{C}\right): \delta[\mathrm{ppm}]=12.08(\mathrm{~s}, 1 \mathrm{H})$, $8.30-8.22(\mathrm{~m}, 2 \mathrm{H}), 8.06(\mathrm{dd}, J=9.2,0.9 \mathrm{~Hz}, 1 \mathrm{H}), 7.93-7.84$ $(\mathrm{m}, 2 \mathrm{H}), 7.79(\mathrm{dd}, J=9.2,0.4 \mathrm{~Hz}, 1 \mathrm{H}), 7.58-7.55(\mathrm{~m}$, 1H), 7.34 (ddd, $J=3.0,2.1,0.9 \mathrm{~Hz}, 1 \mathrm{H}) .{ }^{13} \mathbf{C}\left\{{ }^{1} \mathbf{H}\right\} \mathbf{~ N M R}$ $\left(101 \mathrm{MHz}, \mathrm{DMSO}-d_{6}, 25{ }^{\circ} \mathrm{C}\right): \delta[\mathrm{ppm}]=141.8,141.3$, $140.7,140.0,133.8,129.8,129.2,128.6,128.6,124.4$, 122.2, 121.4, 121.3, 103.9.

\section{Pyrrolo[2,3-a]phenazine (P5) [40]}

The title compound was purified by column chromatography $\left(\mathbf{R}_{\mathbf{f}}=0.49\right.$; ethyl acetate/n-hexane 50:50) as well as by sublimation and isolated as a yellow solid $(159 \mathrm{mg}$, $0.725 \mathrm{mmol}, 58 \%)$. ${ }^{1} \mathrm{H}$ NMR $\left(400 \mathrm{MHz}, \mathrm{DMSO}-d_{6}\right.$, $\left.25^{\circ} \mathrm{C}\right): \delta[\mathrm{ppm}]=12.88(\mathrm{~s}, 1 \mathrm{H}), 8.30-8.23(\mathrm{~m}, 2 \mathrm{H}), 8.13$ $(\mathrm{d}, J=9.1 \mathrm{~Hz}, 1 \mathrm{H}), 7.91(\mathrm{~m}, 2 \mathrm{H}), 7.70(\mathrm{~d}, J=9.0 \mathrm{~Hz}, 1 \mathrm{H})$, $7.57(\mathrm{t}, J=2.7 \mathrm{~Hz}, 1 \mathrm{H}), 6.80-6.77(\mathrm{~m}, 1 \mathrm{H}) .{ }^{13} \mathbf{C}\left\{{ }^{1} \mathbf{H}\right\} \mathbf{N M R}$ $\left(101 \mathrm{MHz}, \mathrm{DMSO}-d_{6}, 25{ }^{\circ} \mathrm{C}\right): \delta[\mathrm{ppm}]=142.2,140.9$, $140.8,134.8,130.0,129.3,128.7,128.2,128.1,128.0$, 126.1, 126.0, 120.5, 104.9.

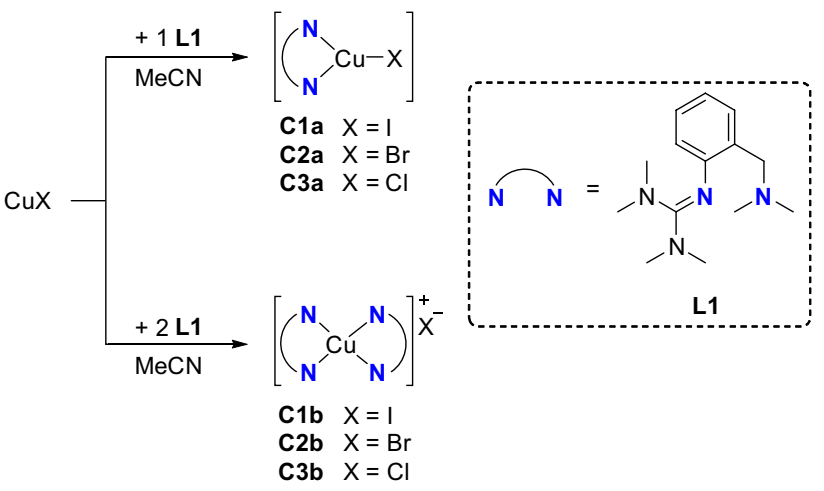

Scheme 1 Synthesis of copper(I) hybrid guanidine complexes $[\mathrm{Cu}(\mathbf{L 1}) \mathrm{X}]$ and $\left[\mathrm{Cu}(\mathbf{L 1})_{2}\right] \mathrm{X}(\mathrm{X}=\mathrm{I}, \mathrm{Br}, \mathrm{Cl})$

\section{Results and discussion}

\section{Synthesis of $\mathrm{Cu}^{\prime}$ complexes}

The hybrid guanidine ligand TMGbenza (L1) was synthesized according to a procedure reported previously [40]. Depending on the copper salt to ligand ratio, monochelate and bischelate copper(I) complexes were formed (Scheme 1). Reaction of equimolar amounts of copper(I) halides $\mathrm{CuX}$ $(\mathrm{X}=\mathrm{I}, \mathrm{Br}, \mathrm{Cl}$ ) with TMGbenza resulted in the formation of neutral monochelate copper(I) complexes $[\mathrm{Cu}(\mathbf{L 1}) \mathrm{I}](\mathbf{C 1 a})$, $[\mathrm{Cu}(\mathbf{L 1}) \mathrm{Br}](\mathbf{C 2 a})$, and $[\mathrm{Cu}(\mathbf{L 1}) \mathrm{Cl}](\mathbf{C 3 a})$ in high yields. All complexes were analyzed by NMR and IR spectroscopy as well as mass spectrometry. Interestingly, proton shifts in the aromatic and aliphatic region are broadened from C1a to C3a (Figs. S1, S10, and S15 in the Supporting Information), which was assigned to the increasing ionic character of the $\mathrm{Cu}-\mathrm{X}$ bond from iodide to chloride.

Single crystals of C1a-C3a suitable for X-ray diffraction were grown by slow diffusion of diethyl ether into a saturated solution of the complex in acetonitrile (Fig. 2 and Table 1). Complexes C1a-C3a crystallize orthorhombic in the space group Pbca (Table S2 in the Supporting Information). The central copper atom $\mathrm{Cu}(1)$ is coordinated in a distorted trigonal-planar fashion by the bidentate hybrid guanidine ligand $\mathbf{L 1}$ and one halide donor. The $\mathrm{Cu}-\mathrm{N}(1)$ bond lengths are significantly shorter than the $\mathrm{Cu}-\mathrm{N}(4)$ bond lengths, revealing the higher donor strength of the guanidine moiety compared to the amine donor function. The decreasing $\mathrm{Cu}-\mathrm{X}$ bond length from complex $\mathbf{C 1 a}$ to $\mathbf{C 3 a}$ correlates with an increasing $\mathrm{Cu}(1)-\mathrm{N}(4)$ bond length. Complex C1a exhibits an approximately Y-shaped geometry with an N(1)$\mathrm{Cu}(1)-\mathrm{X}$ bond angle of $147.63(7)^{\circ}$, which deviates from the ideal $120^{\circ}$ angle due to the restricted bite angle of $\mathbf{L 1}\left(97^{\circ}\right.$ $99^{\circ}$ ). The coordination geometry in C2a and C3a is slightly more distorted Y-shaped, which was also observed in other trigonal-planar complexes [74]. The structure parameter $\rho$ 


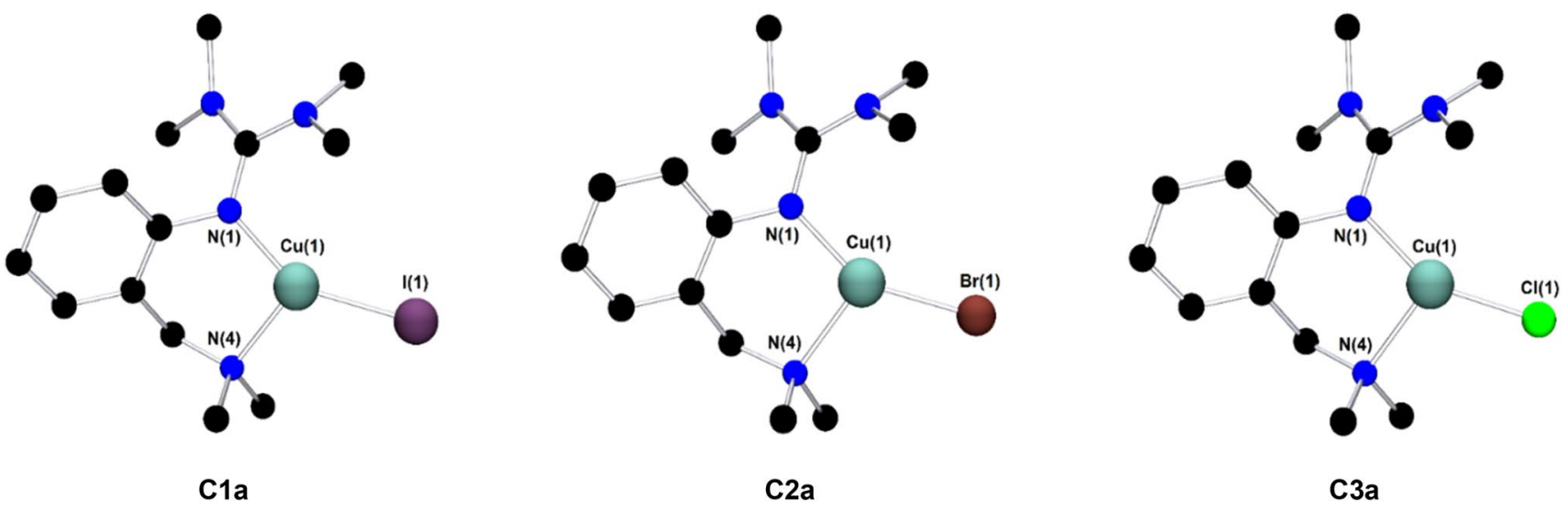

Fig. 2 Molecular structures of the complexes C1a-C3a in the solid state. Hydrogen atoms are omitted for clarity

Table 1 Selected bond lengths $[\AA]$ and angles $\left[{ }^{\circ}\right]$ of the $\mathrm{Cu}^{\mathrm{I}}$ complexes C1a-C3a

\begin{tabular}{llll}
\hline & C1a & C2a & C3a \\
\hline $\mathrm{Cu}(1)-\mathrm{N}(1)$ & $1.958(2)$ & $1.943(3)$ & $1.941(2)$ \\
$\mathrm{Cu}(1)-\mathrm{N}(4)$ & $2.108(3)$ & $2.130(3)$ & $2.151(2)$ \\
$\mathrm{Cu}(1)-\mathrm{X}(1)$ & $2.4486(4)$ & $2.2821(7)$ & $2.1592(8)$ \\
$\mathrm{N}(1)-\mathrm{Cu}(1)-\mathrm{N}(4)$ & $99.34(10)$ & $98.71(12)$ & $97.81(8)$ \\
$\mathrm{N}(1)-\mathrm{Cu}(1)-\mathrm{X}$ & $147.63(7)$ & $149.68(9)$ & $151.66(6)$ \\
$\rho^{\mathrm{a}}$ & 0.98 & 0.98 & 0.99 \\
\hline
\end{tabular}

${ }^{\mathrm{a}} \rho=2 \mathrm{a} /(\mathrm{b}+\mathrm{c})[75]$

was calculated from the $\mathrm{C}-\mathrm{N}$ bond lengths within the guanidine moiety, showing a good delocalization of the double bond within the guanidine unit.

Besides monochelate complexes, bischelate copper(I) complexes $\left[\mathrm{Cu}(\mathbf{L} \mathbf{1})_{2}\right] \mathrm{I}(\mathbf{C} 1 \mathbf{b}),\left[\mathrm{Cu}(\mathbf{L} \mathbf{1})_{2}\right] \mathrm{Br}(\mathbf{C} 2 \mathbf{b})$, and $\left[\mathrm{Cu}(\mathbf{L 1})_{2}\right] \mathrm{Cl}(\mathbf{C} 3 \mathbf{b})$ can be formed in solution. Temperaturedependent ${ }^{1} \mathrm{H}$ DOSY NMR measurements of ligand $\mathbf{L 1}$, monochelate complex C1a, bischelate complex C1b and acetonitrile showed a linear dependency of the diffusion constant and the temperature (Fig. S8). The monochelate species C1a displays a significantly higher diffusion constant than its related bischelate species $\mathbf{C 1 b}$ within the error tolerances $\left(D(\mathbf{C 1 a})=1.81 \pm 0.0310^{-9} \mathrm{~m}^{2} \mathrm{~s}^{-1}\right.$ and $D(\mathbf{C 1 b})=1.65 \pm 0.04$ $10^{-9} \mathrm{~m}^{2} \mathrm{~s}^{-1}$ at $299.7 \mathrm{~K}$ ), revealing a higher dynamic behavior of C1a due to its smaller molecular size and concomitantly ruling out the presence of a dimeric species.

\section{Oxygenation reactions}

Dioxygen activation was achieved by injecting a solution of copper(I) species C1a-C3a in acetonitrile in an oxygensaturated THF solution (Scheme 2).
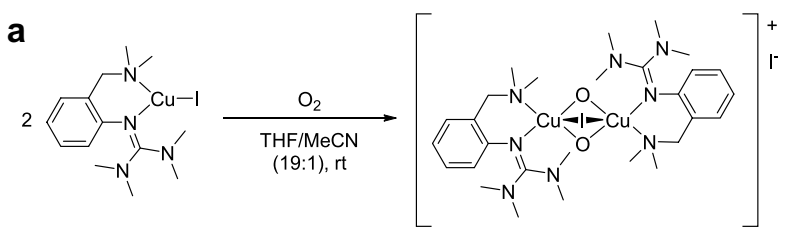

C1a

[01]1]

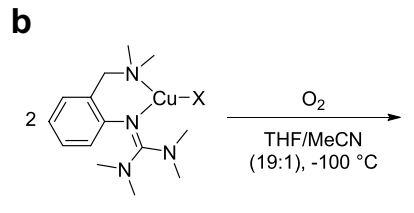

C2a $(X=B r)$ $\mathrm{C} 3 \mathbf{a}(\mathrm{X}=\mathrm{Cl})$

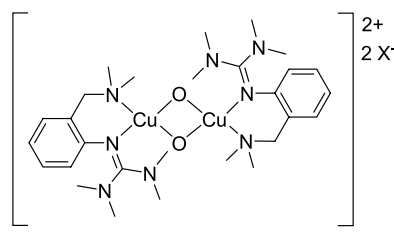

$[01] X_{2}$

Scheme 2 Oxygenation of monochelate complexes C1a-C3a

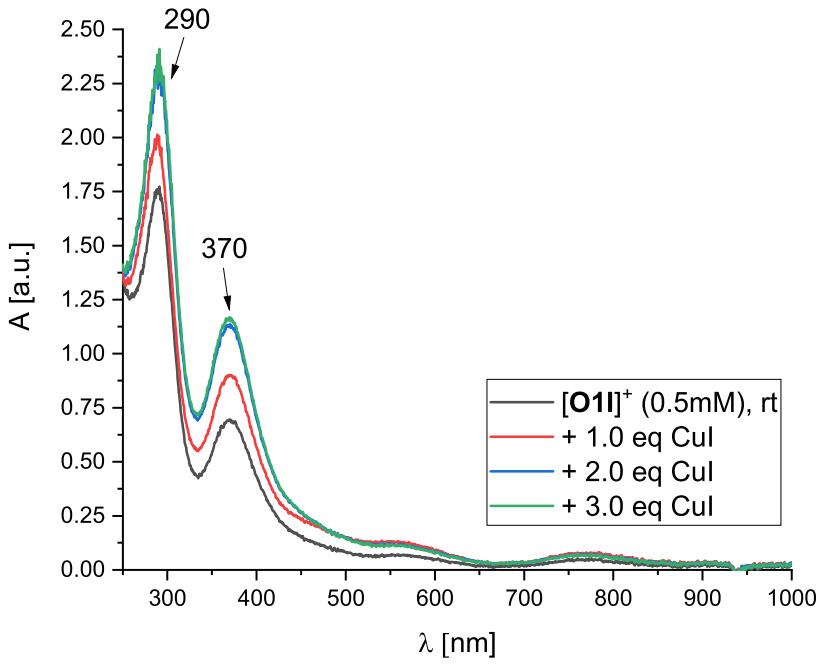

Fig. $3 \mathrm{UV} /$ Vis spectra of the oxygenated C1a to give $[\mathbf{O 1 I}]^{+}$(black) and the titration with $\mathrm{CuI}$ in tetrahydrofuran at room temperature 


\section{UV/Vis spectroscopy}

Oxygenation of monochelate species C1a in tetrahydrofuran was accomplished at room temperature, leading to an immediate color change from colorless to reddish-brown generating a bis( $\mu$-oxido) species within two hours (Fig. 3, black line). The oxygenated species of C1a was stable at room temperature for at least a week, demonstrating its high stability. By titration experiments and DFT calculations (vide infra), we deduce this bis( $\mu$-oxido) species to contain a $[\mathbf{O 1 I}]^{+}$cation.

The black UV/Vis spectrum in Fig. 3 exhibits two distinct absorption bands at $290 \mathrm{~nm}$ and $370 \mathrm{~nm}$ after two hours at room temperature, which are in the typical range of bis( $\mu$-oxido) species $[5,6,10]$. But the absorption bands document a blueshift by $20 \mathrm{~nm}$ (for the $370 \mathrm{~nm}$ absorption) or by $10 \mathrm{~nm}$ (for the $290 \mathrm{~nm}$ absorption) relative to our recently reported system $[\mathbf{O 1}]\left(\mathrm{PF}_{6}\right)_{2}$, which showed spectral features at $280 \mathrm{~nm}\left(40,000 \mathrm{M}^{-1} \mathrm{~cm}^{-1}\right)$ and $392 \mathrm{~nm}$ $\left(21,000 \mathrm{M}^{-1} \mathrm{~cm}^{-1}\right)$ [40]. Same observations were made when C1a was oxygenated at $-80^{\circ} \mathrm{C}$ (Fig. S20 in the Supporting Information).

Compared to bis( $\mu$-oxido) complex [O1] $\left(\mathrm{PF}_{6}\right)_{2}$, however, it is conspicuous that the extinction of the absorption bands is significantly lower than expected from previous data, indicating no full formation of the bis( $\mu$-oxido) complex (65\%). Since copper iodide species are known for the formation of iodidocuprate clusters $\left[\mathrm{Cu}_{\mathrm{y}} \mathrm{I}_{\mathrm{x}+\mathrm{y}}\right]^{\mathrm{x}-}\left[{ }^{2}\right.$ (76-78], several titration experiments were performed to investigate the formed bis( $\mu$-oxido) species and its present anions. Upon titration of $[\mathbf{O 1 I}]^{+}$with hybrid guanidine ligand $\mathbf{L 1}$ the absorption bands of $[\mathbf{O 1 I}]^{+}$remained constant (Fig. S32), showing no effect of additional ligand on the bis( $\mu$-oxido) complex. Similar observations were made by using iodide source tetrabutylammonium iodide as titrant (Fig. S33), revealing no influence of the amount of iodide on $[\mathbf{O 1 I}]^{+}$. The titration of $[\mathbf{O 1 I}]^{+}$with one and two equivalents of copper salt $\left[\mathrm{Cu}(\mathrm{MeCN})_{4}\right] \mathrm{PF}_{6}$ resulted in a slight decrease of the absorption band at $370 \mathrm{~nm}$ (Fig. S34), resulting from the occurrence of a slight diluting effect while copper salt addition.

When $[\mathbf{O 1 I}]^{+}$is titrated with equivalents of copper iodide (Fig. 3), a slight color change to deeper reddish-brown was observed. The absorption band at $370 \mathrm{~nm}$ increased significantly upon addition of one and two equivalents of copper iodide and remained approximately constant upon addition of a third equivalent of copper iodide. As a result, two equivalents of copper iodide are necessary to achieve the complete formation of the bis( $\mu$-oxido) species, indicating the formation of iodidocuprate anions with a copper-to-iodide ratio of $1: 2$ in the outer sphere of the complex cation $[\mathbf{O 1 I}]^{+}$. Therefore, a Cu-I-ratio of the anion of 1:2 is required to achieve a quantitative formation of the bis( $\mu$-oxido) complex, implying small iodidocuprate anions with the stoichiometry of twice $\left[\mathrm{CuI}_{2}\right]^{-}$or $\left[\mathrm{Cu}_{2} \mathrm{I}_{4}\right]^{2-}$.

Direct oxygenation of the $\mathrm{Cu}^{\mathrm{I}}$ adduct $\mathrm{C1a} \cdot \mathrm{CuI}$ in tetrahydrofuran confirmed the previous titration results, leading to similar absorption features at $290 \mathrm{~nm}$ $\left(50,000 \mathrm{M}^{-1} \mathrm{~cm}^{-1}\right)$ and $370 \mathrm{~nm}\left(22,000 \mathrm{M}^{-1} \mathrm{~cm}^{-1}\right)$ within two hours at room temperature (Fig. 3, blue line). ${ }^{1} \mathrm{H}$ NMR measurements revealed only marginal discrepancies between C1a and C1a.CuI (Fig. S7), which results from a very similar chemical environment to enable the same formed bis( $\mu$-oxido) complex $[\mathbf{O 1 I}]\left(\mathrm{CuI}_{2}\right)$. The extinction coefficient of $[\mathbf{O 1 I}]\left(\mathrm{CuI}_{2}\right)$ is slightly higher than the one of $[\mathbf{O 1}]\left(\mathrm{PF}_{6}\right)_{2}$. The absorption bands were also stable for at least seven days. The CT bands at $450 \mathrm{~nm}$ $\left(4300 \mathrm{M}^{-1} \mathrm{~cm}^{-1}\right)$ and $570 \mathrm{~nm}\left(1700 \mathrm{M}^{-1} \mathrm{~cm}^{-1}\right)$ were found to be more intense compared to the oxygenation of C1a as expected. This agrees with the more intense red color of the reaction solution, resulting from the interaction of the guanidine $\pi$-system and the iodidocuprate anion (see DFT section, vide infra). The high stability of $[\mathbf{O 1 I}]\left(\mathrm{CuI}_{2}\right)$ is remarkable because the stability of most bis( $\mu$-oxido) species is limited to very low temperatures $[5,6]$. Furthermore, complex $[\mathbf{O 1 I}]\left(\mathrm{CuI}_{2}\right)$ represents to the best of our knowledge the first example of an iodidocuprate-stabilized bis( $\mu$-oxido) species.

In analogy to complex C1a, oxygenation of the monochelate complexes C2a and C3a resulted in the formation of a bis( $\mu$-oxido) species, exhibiting the characteristic absorption features (Table 2). Nevertheless, the oxygenation process required low temperatures at $-100{ }^{\circ} \mathrm{C}$ due to the high reactivity of the greenish bis( $\mu$-oxido) intermediate, resembling the characteristics of $[\mathbf{O 1}]\left(\mathrm{PF}_{6}\right)_{2}[40]$. Both $[\mathbf{O 1}] \mathrm{Br}_{2}$ and $[\mathbf{O 1}] \mathrm{Cl}_{2}$ were formed within seconds at $-100{ }^{\circ} \mathrm{C}$ and decayed very quickly afterwards (Scheme $2 \mathrm{~b}$ and Sects. 3.2-3.3 in the Supporting Information). The $\mathrm{UV} / \mathrm{Vis}$ spectra of $[\mathbf{O 1}] \mathrm{Br}_{2}$ and $[\mathbf{O 1}] \mathrm{Cl}_{2}$ are very similar to $[\mathbf{O 1}]\left(\mathrm{PF}_{6}\right)_{2}$ (see Table 2) and show no hint for a halidebridged species as $[\mathbf{O 1 I}]^{+}$. This is in accordance with the smaller anion size of chloride and bromide.

Surprisingly, similar to the oxygenation of the monochelate species C1a-C3a, a solution of bischelate complex C1b-C3b can be oxygenated at low temperatures as well. The resulting bis( $\mu$-oxido) species $[\mathbf{O 1}]^{2+}$ depicted similar

Table 2 Experimental UV/Vis transitions of the bis( $\mu$-oxido) species $[\mathbf{O 1}]\left(\mathrm{PF}_{6}\right)_{2},[\mathbf{O 1 I}]\left(\mathrm{CuI}_{2}\right),[\mathbf{O 1}] \mathrm{Br}_{2}$ and $[\mathbf{O 1}] \mathrm{Cl}_{2}$

\begin{tabular}{lll}
\hline & $\lambda[\mathrm{nm}]\left(\varepsilon\left[\mathrm{M}^{-1} \mathrm{~cm}^{-1}\right]\right)$ \\
\hline$[\mathbf{O 1}]\left(\mathrm{PF}_{6}\right)_{2}[40]$ & $392(21,000)$ & $280(40,000)$ \\
{$[\mathbf{O 1 I}]\left(\mathrm{CuI}_{2}\right)$} & $370(22,000)$ & $290(50,000)$ \\
{$[\mathbf{O 1}] \mathrm{Br}_{2}$} & $399(21,000)$ & $270(50,000)$ \\
{$[\mathbf{O 1}] \mathrm{Cl}_{2}$} & $386(21,000)$ & $270(50,000)$ \\
\hline
\end{tabular}


absorption features compared to the oxygenated complexes C1a-C3a, except the extinction was significantly lower. With a maximum of approximately $50 \%$ quantity of the formed bis( $\mu$-oxido) species, the oxygenation process indicates an existing dynamic equilibrium between monochelate and bischelate species in solution, in which only the monochelate complex reacts with dioxygen. The bischelate species is resistant to dioxygen due to the saturated coordination sites of its copper center by two equivalents of ligand $\mathbf{L 1}$.

\section{Mass spectrometry}

This dynamic equilibrium was also observed by using cryoUHR-ESI mass spectrometry: measurements of the oxygenation reactions of C1a-C3a were performed at $-100^{\circ} \mathrm{C}$ immediately after the injection of copper(I) complex solution and again after approximately three minutes. Oxygenating C1a-C3a, the isotopic pattern and corresponding $\mathrm{m} / \mathrm{z}$ value of $\left[\mathrm{Cu}(\mathbf{L 1})_{2}\right]^{+}$were found immediately after the injection in the positive mode (Fig. S23). Accordingly, the isotopic pattern and corresponding $\mathrm{m} / \mathrm{z}$ values of $\left[\mathrm{CuX}_{2}\right]^{-}$were found in the negative mode in all cases. The intensity of

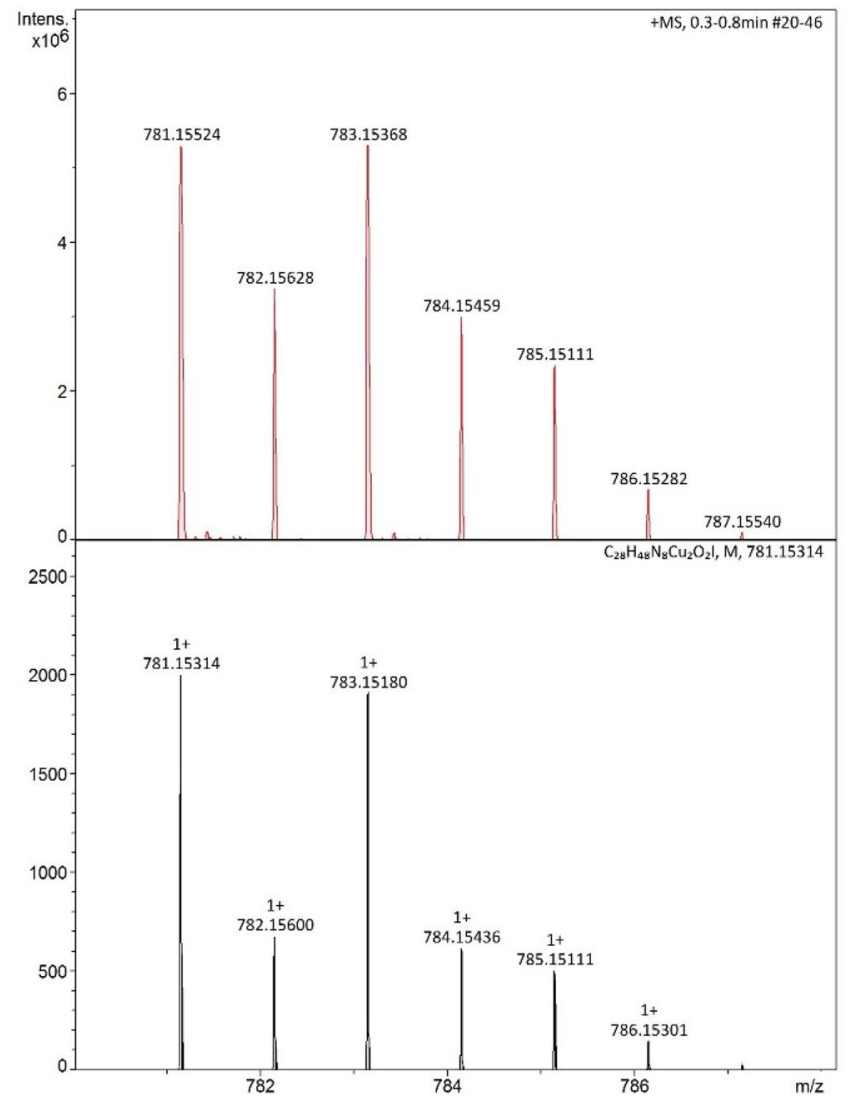

these signals decreased after a few minutes in favor of the formed corresponding bis( $\mu$-oxido) species $[\mathbf{O 1}](\mathrm{X})^{+}(\mathrm{X}=\mathrm{I}$, $\mathrm{Br}, \mathrm{Cl})$. Measurements of the oxygenation reaction of both C1a and $\mathbf{C 1 a} \cdot \mathrm{CuI}$ in tetrahydrofuran exhibited the isotopic pattern of the monocationic species $[\mathbf{O 1 I}]^{+}$and $[\mathrm{O1}]\left(\mathrm{CuI}_{2}\right)^{+}$ in the positive mode (Fig. 4), confirming the occurrence of iodidocuprate anions stabilizing the bis( $\mu$-oxido) core. By using the negative mode, the isotopic pattern and corresponding $\mathrm{m} / \mathrm{z}$ values of iodide and $\left[\mathrm{CuI}_{2}\right]^{-}$were detected in both oxygenation reactions (Figs. S24 and S25). The isotopic pattern and corresponding $\mathrm{m} / \mathrm{z}$ values of the oxygenation of C2a and C3a were also observed, exhibiting the mass spectrum of the monocationic species $[\mathrm{O1}](\mathrm{Br})^{+}$ and $[\mathbf{O 1}](\mathrm{Cl})^{+}$in the positive mode (Figs. S26 and S28). Interestingly, only bromido- and chloridocuprate anions were detected in the negative mode during both measurement times when oxygenating C2a and C3a (Figs. S27 and S29). Bromide and chloride were observed in neither case, which is in accordance with the occurring equilibrium and the very fast formation of the bis( $\mu$-oxido) species $[01] \mathrm{Br}_{2}$ and $[\mathbf{O 1}] \mathrm{Cl}_{2}$. It is also worth to mention that only the halidocuprate anions with the composition of $\left[\mathrm{CuX}_{2}\right]^{-}(\mathrm{X}=\mathrm{I}, \mathrm{Br}$, $\mathrm{Cl}$ ) were detected during the reaction (Figs. S24, S27, S29),

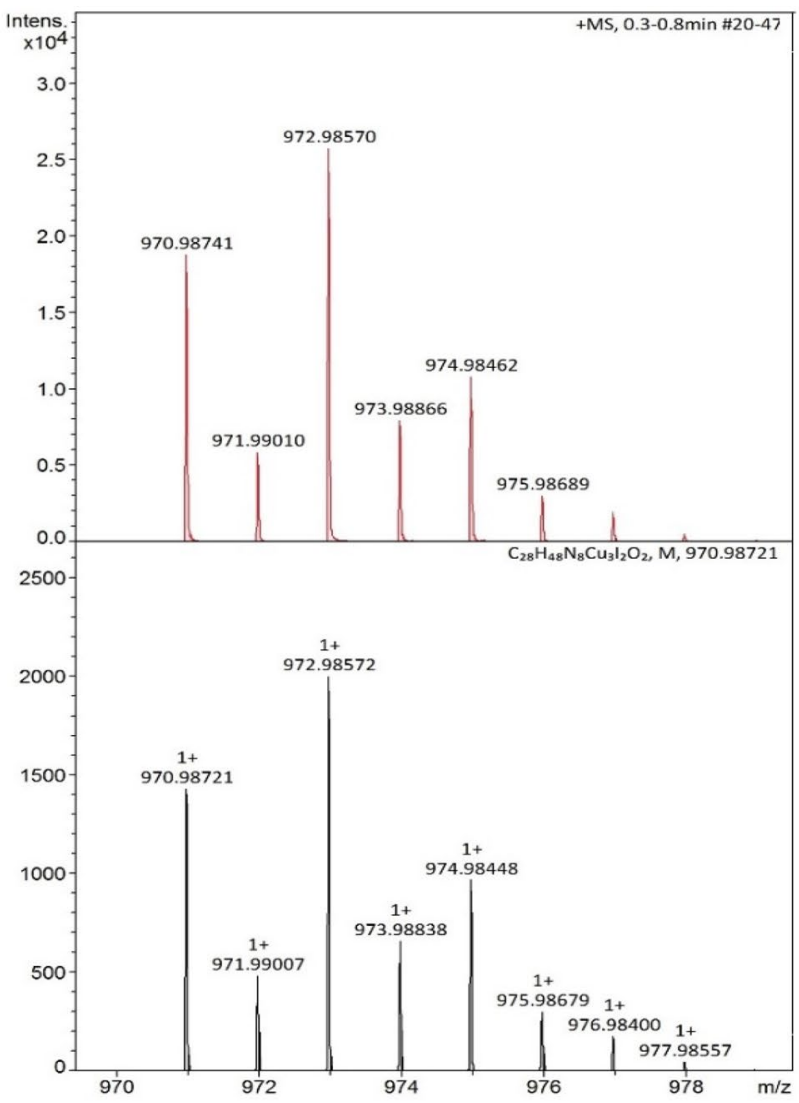

Fig. 4 Cryo-UHR-ESI mass spectrometry of $[\mathbf{O 1 I}]^{+}$(left) and $[\mathbf{O 1}]\left(\mathrm{CuI}_{2}\right)^{+}$(right) in tetrahydrofuran at $-80{ }^{\circ} \mathrm{C}$, which were observed in the oxygenation of C1a and C1a.CuI (red: experimental, black: calculated) 


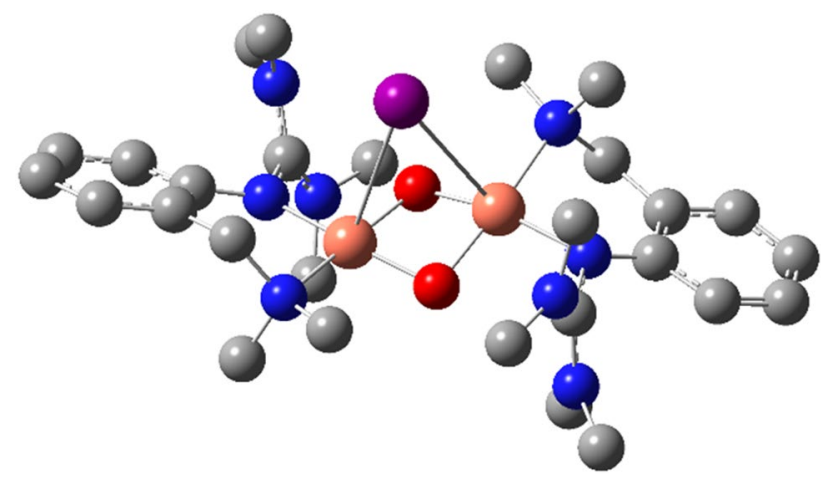

Fig. 5 Calculated structure of $[\mathbf{O 1 I}]^{+}$(TPSSh/def2-TZVP, THFPCM, GD3BJ)

Table 3 Selected bond lengths $[\AA$ ] $]$ and $\mathrm{Cu} \cdots \mathrm{Cu}$ distance $[\AA]$ of $[\mathbf{O 1 I}]^{+}$(TPSSh/def2-TZVP, THF-PCM, GD3BJ)

\begin{tabular}{ll}
\hline & [O1I $^{+}$ \\
\hline $\mathrm{Cu}-\mathrm{N}$ (gua) & $1.930 / 1.925$ \\
$\mathrm{Cu}-\mathrm{N}($ amine) & $1.963 / 1.9661$ \\
$\mathrm{Cu}-\mathrm{O}$ & $1.810 / 1.805 / / 1.805 / 1.803$ \\
$\mathrm{Cu}-\mathrm{I}$ & $3.395 / 3.511$ \\
$\mathrm{Cu} \cdots \mathrm{Cu}$ & 2.689 \\
\hline
\end{tabular}

presumably due to the high reactivity of halidocuprates in solution compared to often observed larger clusters in the solid-state [76-78].

\section{DFT study on [01I] ${ }^{+}$and [01] ${ }^{2+}$}

DFT calculations were performed to investigate the influence of the iodide in the bis( $\mu$-oxido) species $[\mathbf{O 1 I}]^{+}$. Simulations confirm the presence of an iodide-bridged bis( $\mu$-oxido) species (Fig. 5). Selected bond lengths and the $\mathrm{Cu} \cdots \mathrm{Cu}$ vector are summarized in Table 3. This structure motif was also observed for the bis( $\mu$-alkoxido) dicopper(II) complex of another guanidine system [39]. The iodide bridge enforces a slight butterfly distortion of the $\mathrm{Cu}_{2} \mathrm{O}_{2}$ moiety. The selected bond lengths are slightly smaller than for a typical bis $(\mu-$ oxido) species $[5,6]$.

TD-DFT calculations were performed to analyze the observed blueshift of the two characteristic bands in the $\mathrm{UV} / \mathrm{Vis}$ spectra of $[\mathbf{O 1}]^{2+}$ and $[\mathbf{O 1 I}]^{+}$. In the bis( $\mu$-oxido) species $[\mathbf{O 1}]\left(\mathrm{PF}_{6}\right)_{2}$, the experimental absorption band at $392 \mathrm{~nm}$ (TD-DFT: $366 \mathrm{~nm}$ ) results from a transition of the bonding interaction of the $\mathrm{Cu} d$ orbitals with the $\sigma^{*}$ orbital (HOMO-8 in Fig. 6, left) to the antibonding interaction of $\mathrm{Cu}$ d orbitals with the $\pi_{\sigma}{ }^{*}$ orbital (LUMO +1 in Fig. 6, left).

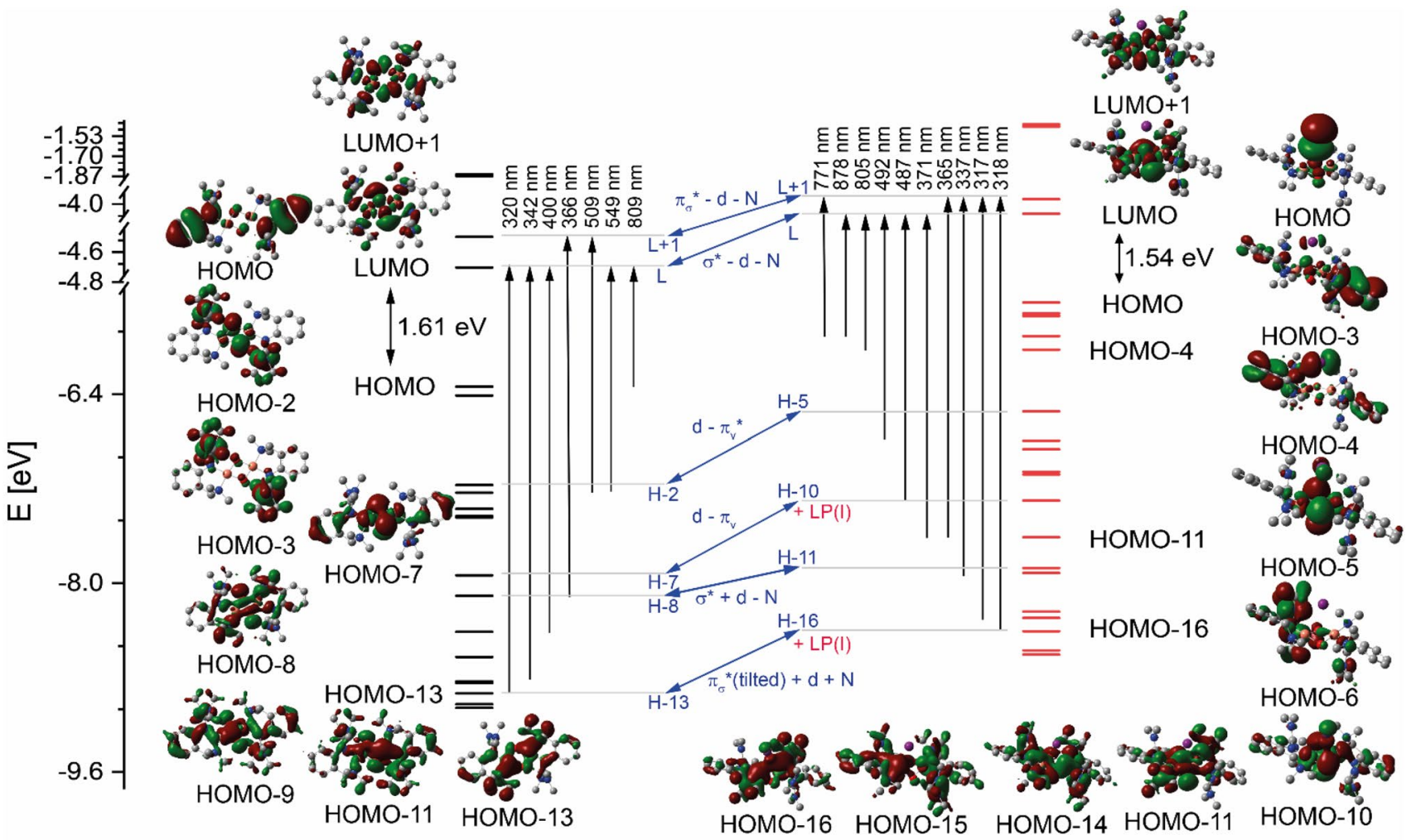

Fig. 6 Molecular orbital and energy correlation of the $[\mathbf{O 1}]^{2+}$ species (left) and of the $[\mathbf{O O 1 I}]^{+}$species (right). Main excitations are summarized (calculated by TD-DFT). The corresponding interactions of the MO and the influence of the iodide of the UV/vis spectra (middle) are presented 
The experimentally found transition at $280 \mathrm{~nm}$ (TD-DFT: $320 \mathrm{~nm}$ ) represents the transition from the bonding interaction of the $\mathrm{Cu} d$ orbitals and the $\pi_{\sigma}{ }^{*}$ orbital (HOMO-13 in Fig. 6, left) to the antibonding interaction of the $\mathrm{Cu} \mathrm{d}$ orbitals with the $\sigma^{*}$ orbital (LUMO in Fig. 6, left). These classical transitions of bis( $\mu$-oxido) species were also found for other guanidine-stabilized bis( $\mu$-oxido) species $[31,79]$. Moreover, two additional transitions to the LUMO were calculated: one from the HOMO-9 (bonding interaction of the $\mathrm{Cu} \mathrm{d}$ orbitals and the $\sigma$ of the bis( $\mu$-oxido) unit; TD-DFT: $400 \mathrm{~nm}$ ) and the second from the HOMO-11 (antibonding interaction of the $\mathrm{Cu} d$ orbitals and the $\sigma^{*}$ orbital of the bis( $\mu$-oxido) moiety, TD-DFT: $342 \mathrm{~nm}$ ). The weaker transitions at higher wavelengths are transitions from the lone pair of the N(amine) to the LUMO or LUMO +1 or at even higher wavelengths of the $\pi^{*}$ orbitals of the ligand to the LUMO.

The iodide in $[\mathbf{O 1 I}]^{+}$possesses three lone pairs (HOMO - HOMO-2), which cause a shift of three orbitals in comparison to the $[\mathbf{O 1}]^{2+}$ species. Therefore, the antibonding interaction of the $\mathrm{Cu} d$ orbitals and the $\pi_{\mathrm{v}}{ }^{*}$ orbital of the bis( $\mu$-oxido) moiety represent the HOMO-2 in $[\mathbf{O 1}]^{2+}$ and the HOMO-5 in $[\mathbf{O 1 I}]^{+}$(Fig. 6, Table S4 and S5). The iodide LP is involved in other molecular orbitals, resulting in a more complex MO scheme of the iodide-bridged bis $(\mu$ oxido) core in comparison to the MO of the "simpler" bis $(\mu$ oxido) core $[\mathbf{O 1}]^{2+}$. In $[\mathbf{O 1 I}]^{+}$, only one classical transition was observed: the bonding interaction of the $\mathrm{Cu} d$ orbitals with the $\sigma^{*}$ orbital of the bis( $\mu$-oxido) moiety (HOMO-11 in Fig. 6, right) to antibonding interaction of $\mathrm{Cu} d$ orbitals with the $\pi_{\sigma}{ }^{*}$ orbital (LUMO +1 in Fig. 6 , right). The calculated transitions at $318 \mathrm{~nm}$ and $337 \mathrm{~nm}$ contain iodide contributions. The transition at $318 \mathrm{~nm}$ is a bonding interaction of the $\pi_{\sigma}{ }^{*}$ orbital and $\mathrm{Cu} \mathrm{d}$ orbitals and the LP of the iodide (HOMO-16, Fig. 6, right) with the LUMO + 1. The intense transition at $337 \mathrm{~nm}$ is the transition from the HOMO-14 (antibonding interaction of the $\mathrm{Cu}$ d orbitals and the $\sigma$ of the bis( $\mu$-oxido) core, Fig. 6 , right) and additionally the HOMO16 to the LUMO. There are two other transitions in the classical region: the transition at $317 \mathrm{~nm}$, the transition of the HOMO-15 (bonding interaction of the linear combination of $\pi_{\mathrm{v}}$ with $\pi_{\sigma}$ with $\mathrm{Cu}$ d orbitals, Fig. 6 , right) to the LUMO +1 and the transition at $371 \mathrm{~nm}$, the HOMO-11 to the LUMO. The tailing of the $379 \mathrm{~nm}$ band in the experimental UV/Vis spectrum is caused by two transitions: a transition from the HOMO-10 (antibonding interaction of the $\mathrm{Cu}$ d orbitals with the $\pi_{\mathrm{v}}$ and bonding interaction with the LP of the iodide, Fig. 6, right) to the LUMO and a transition of the $\pi^{*}$ orbitals of the guanidine moiety (HOMO-6) to the LUMO +1 . The transitions at higher wavelengths are all interactions of the ligand L1. The TD-DFT calculations predict two interactions of the $\pi^{*}$ orbitals of the whole ligand system (HOMO3, Fig. 6, right) to the LUMO $+1(771 \mathrm{~nm})$ and the LUMO

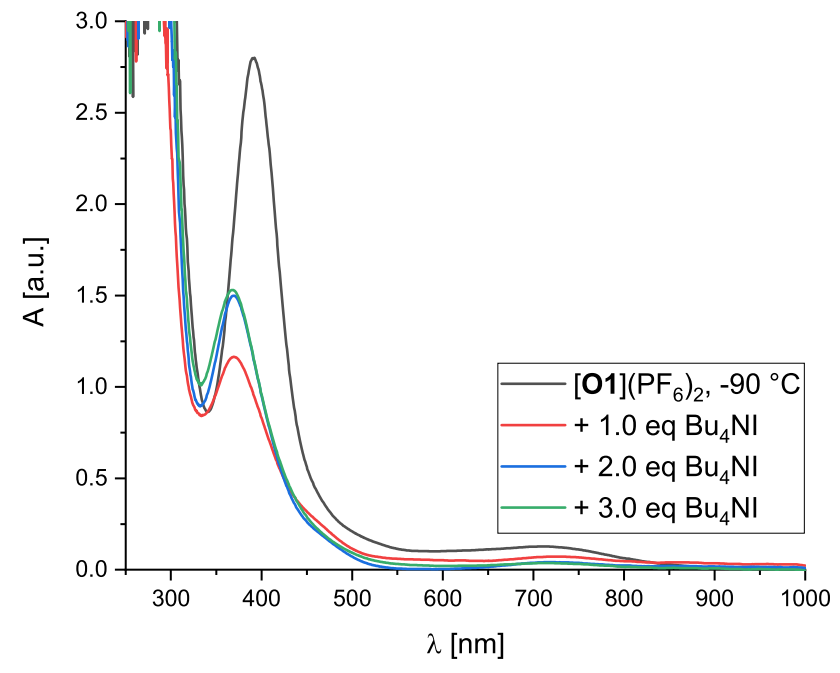

Fig. $7 \mathrm{UV} /$ Vis spectra of the salt metathesis of $[\mathbf{O 1}]\left(\mathrm{PF}_{6}\right)_{2}(1.25 \mathrm{mM})$ with $\mathrm{Bu}_{4} \mathrm{NI}$ in tetrahydrofuran at $-90{ }^{\circ} \mathrm{C}$

(878 nm) and one of the $\pi^{*}$ orbitals of $\mathbf{L} \mathbf{1}$ and the LP of the iodide (HOMO-4, Fig. 6, right) to the LUMO (805 nm). These calculated transitions from the TD-DFT study explain the different UV/Vis spectra of $[\mathbf{O 1}]^{2+}$ and $[\mathbf{O} 1 \mathbf{I}]^{+}$.

\section{Salt metathesis}

Since the bis( $\mu$-oxido) species $[\mathbf{O 1 I}]\left(\mathrm{CuI}_{2}\right)$ showed an unusual high stability at room temperature, especially compared to its very similar relative $[\mathbf{O 1}]\left(\mathrm{PF}_{6}\right)_{2}$, titration experiments were performed to interconvert both species (Fig. 7). Starting from the khaki-colored bis( $\mu$-oxido) complex $[\mathrm{O1}]\left(\mathrm{PF}_{6}\right)_{2}$ [40] in tetrahydrofuran at $-90{ }^{\circ} \mathrm{C}$, aliquots of the iodide source $\mathrm{Bu}_{4} \mathrm{NI}$ were added stepwise.

Upon addition of one equivalent of $\mathrm{Bu}_{4} \mathrm{NI}$ the reaction solution changed its color from khaki to greenish-brown. The absorption band at $390 \mathrm{~nm}$ shifted to $370 \mathrm{~nm}$ within minutes under an immense loss in intensity and remained constant after $40 \mathrm{~min}$. The iodide-bridged bis( $\mu$-oxido) core and the iodidocuprate anion are formed according to a different stoichiometry causing the loss in intensity in the UV/Vis spectrum (indicating the decay of the original $[\mathbf{O 1}]\left(\mathrm{PF}_{6}\right)_{2}$ species). The formation of iodidocuprates provide an additional supporting ligand for the reactive bis( $\mu$-oxido) core. Adding a second equivalent of $\mathrm{Bu}_{4} \mathrm{NI}$ to the reaction solution led to a color change to reddish-brown, as observed for the direct oxygenation of C1a. The bis( $\mu$-oxido) band at $370 \mathrm{~nm}$ increased significantly, which stabilized after one hour. No further changes in color and spectral features were observed by adding a third equivalent of $\mathrm{Bu}_{4} \mathrm{NI}$, revealing a completed salt metathesis after the addition of two equivalents of the iodide source. Upon warming up the reaction solution to room temperature the absorption band at $370 \mathrm{~nm}$ remained 


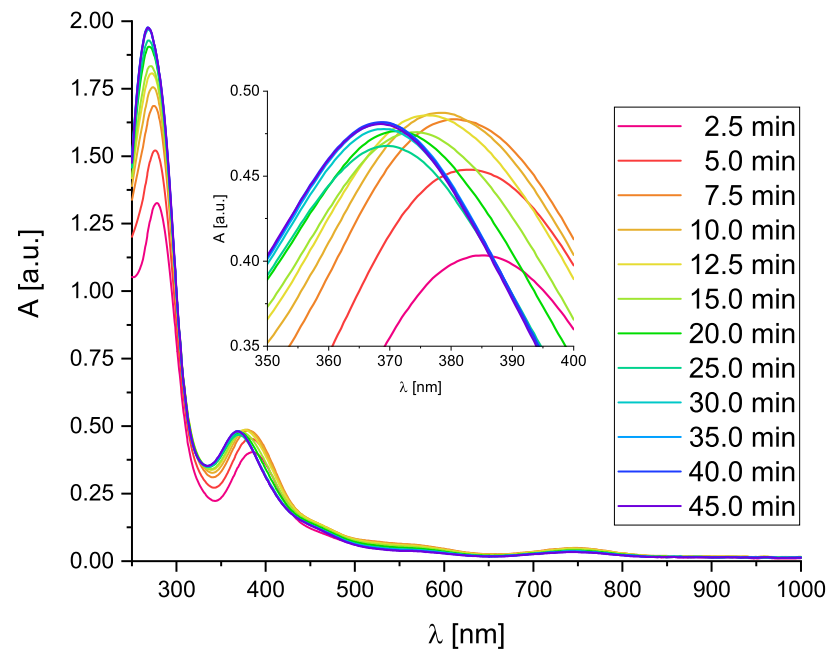

Fig. $8 \mathrm{UV} /$ Vis spectra of the formation of $[\mathbf{O 1 I}]\left(\mathrm{CuI}_{2}\right)(0.25 \mathrm{mM})$ in tetrahydrofuran at $-90{ }^{\circ} \mathrm{C}$ (Inset: expansion of the formation of $\left.[\mathbf{O 1 I}]\left(\mathrm{CuI}_{2}\right)\right)$

constant, demonstrating that an easy exchange of the present anion increases the stability of the bis( $\mu$-oxido) species by over $100{ }^{\circ} \mathrm{C}$. These salt metatheses were also performed by using halide sources $\mathrm{Bu}_{4} \mathrm{NX}(\mathrm{X}=\mathrm{Br}, \mathrm{Cl})$ leading to the bis( $\mu$-oxido) species $[\mathbf{O 1}] \mathrm{Br}_{2}$ and $[\mathbf{O 1}] \mathrm{Cl}_{2}$ (Figs. S33 and S34).

\section{Competitive oxygenation of $\mathrm{C} 1 \mathrm{a}$ and [ $\mathrm{Cu}(\mathrm{L} 1)(\mathrm{MeCN})]$ $\mathrm{PF}_{6}$}

Although the formation of $[\mathrm{O1}]\left(\mathrm{PF}_{6}\right)_{2}$ takes just a few minutes at $-90^{\circ} \mathrm{C}$ [40], the oxygenation process of C1a is only completed after two hours at room temperature. Therefore, copper(I) species $\mathbf{C 1 a}$ and $[\mathrm{Cu}(\mathbf{L 1})(\mathrm{MeCN})] \mathrm{PF}_{6}$ were oxygenated simultaneously at $-90{ }^{\circ} \mathrm{C}$ to investigate the competitive formation of the resulting bis( $\mu$-oxido) species (Fig. 8).

Initial formation of $[\mathbf{O 1}]\left(\mathrm{PF}_{6}\right)_{2}$ was observed within the first three minutes (absorption band at $390 \mathrm{~nm}$ ), as expected [40]. A wavelength shift to $380 \mathrm{~nm}$ after $10 \mathrm{~min}$, which is stable for a few minutes, indicated the occurrence of both species $[\mathbf{O 1}]\left(\mathrm{PF}_{6}\right)_{2}$ and $[\mathbf{O 1 I}]\left(\mathrm{CuI}_{2}\right)$. After $30 \mathrm{~min}$ the absorption band was shifted further to $370 \mathrm{~nm}$ and remained constant, henceforth resulting from the formation of the more stable bis( $\mu$-oxido) dicopper(III) iodidocuprate complex $[\mathbf{O 1 I}]\left(\mathrm{CuI}_{2}\right)$. The absorbance in the UV/Vis spectrum remained constant upon transition to $[\mathbf{O 1 I}]\left(\mathrm{CuI}_{2}\right)$ due to the stabilizing effects of the iodidocuprates on the bis( $\mu$-oxido) core. The coordination of these anions to a copper center caused the wavelength shift of the complex cation. Furthermore, it has to be highlighted that the complexes $[\mathbf{O 1}]\left(\mathrm{PF}_{6}\right)_{2}$ and $[\mathbf{O 1 I}]\left(\mathrm{CuI}_{2}\right)$ are formed in totally different time scales: $[\mathbf{O 1}]\left(\mathrm{PF}_{6}\right)_{2}$ within minutes and $[\mathbf{O 1 I}]\left(\mathrm{CuI}_{2}\right)$ within hours.
Table 4 Catalytic oxygenation reactions of polycyclic aromatic alcohols mediated by bis( $\mu$-oxido) species $[\mathbf{O 1 I}]\left(\mathrm{CuI}_{2}\right)$

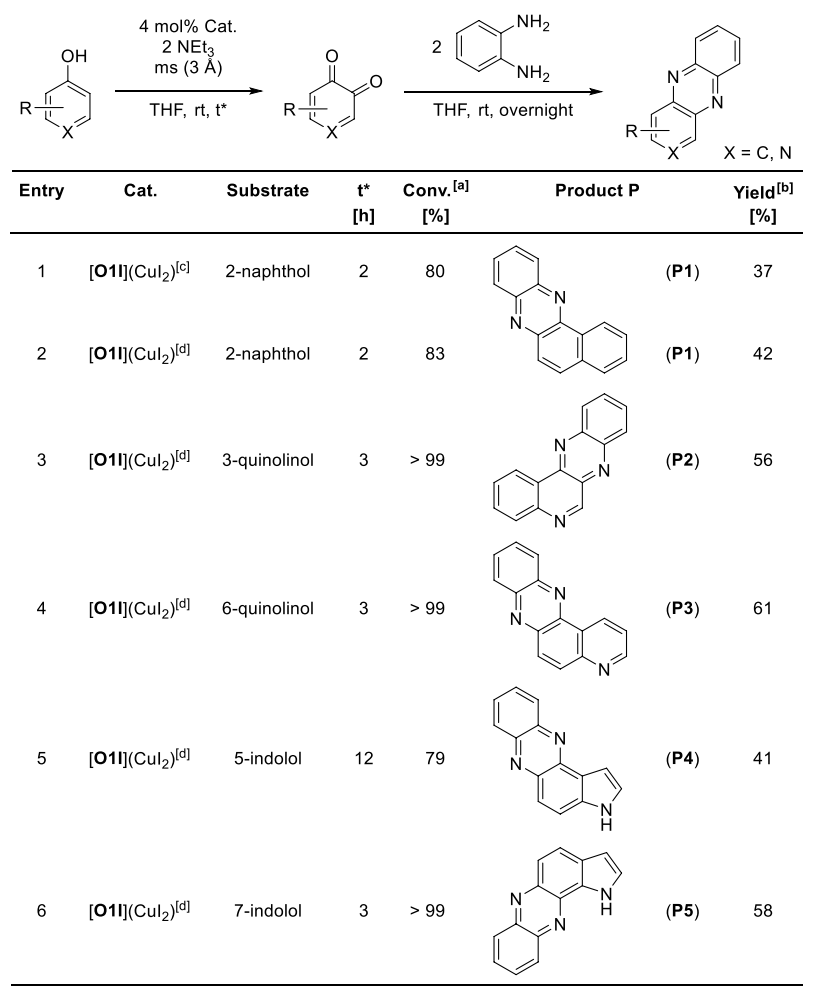

[a] Conversion of the substrate determined by ${ }^{1} \mathrm{H}$ NMR spectroscopy. [b] Isolated yield of the phenazine after column chromatography and/or sublimation. [c] Efficient catalyst concentration of approximately $2 \mathrm{~mol} \%$ due to oxygenation of C1a. [d] Catalyst formed by oxygenation of C1a.Cul.

\section{Catalytic oxygenation reactions of phenolic substrates}

The bis( $\mu$-oxido) complex $[\mathbf{O 1}]\left(\mathrm{PF}_{6}\right)_{2}$ has already proven its remarkable ability to activate $\mathrm{C}-\mathrm{H}$ bonds in hydroxylation reactions towards many different substrate classes [40]. Only few tyrosinase model systems are known to promote catalytic substrate conversion and even fewer catalysts exhibited room temperature stability and catalytic activity [10].

Since a simple switch of the present anion achieved a great leap in stability, bis( $\mu$-oxido) species $[\mathbf{O 1 I}]\left(\mathrm{CuI}_{2}\right)$ was tested in catalytic oxygenation reactions of phenolic substrates at room temperature. In this reaction, polycyclic aromatic alcohols were oxygenated in ortho-position and the resulting quinones were captured by 1,2-phenylenediamine in a condensation reaction to give stable phenazines (Table 4). This strategy was already used earlier to capture the reactive quinones $[40,80]$. From a library of possible substrates, polycyclic aromatic alcohols with two quinone product possibilities were chosen to investigate the influence of the iodide-bridged bis( $\mu$-oxido) species on the selectivity of the hydroxylation reaction. Upon two substrates leading to the same phenazine product, only one of them were tested. The reaction procedure was adapted by a protocol which 
originated from Bulkowski and was modified by Tuczek and co-workers [17, 81]. A catalyst concentration of $4 \mathrm{~mol} \%$ referred to the full formation of $[\mathbf{O 1 I}]\left(\mathrm{CuI}_{2}\right)$ was chosen according to our study on $[\mathbf{O 1}]\left(\mathrm{PF}_{6}\right)_{2}$. [40] Triethylamine was used as auxiliary base in two equivalents referred to the substrate. Flame-dried molecular sieve ( $3 \AA$ ) serve as an intercepting agent for produced water molecules during the reaction to avoid catalyst decomposition since bis( $\mu$-oxido) complex $[\mathbf{O 1 I}]\left(\mathrm{CuI}_{2}\right)$ is only stable towards a small amount of water (Fig. S35 in the Supporting Information).

The conversion of 2-naphthol was investigated by comparing the oxygenation process in the presence of both precursor species C1a (Table 2, entry 1) and C1a.CuI (entry 2), as $[\mathbf{O 1 I}]\left(\mathrm{CuI}_{2}\right)$ was not formed quantitatively when C1a was oxygenated. Although 2-naphthol has two possible hydroxylation positions, the location of the electrophilic attack was predicted by a large value of the negative Fukui function, leading to bent phenazines [40]. 2-Naphthol was transformed into its quinone form within two hours in $>80 \%$ conversion and subsequently converted into benzo[a]phenazine (P1), which was purified by column chromatography to afford $37-42 \%$ isolated yield (entries 1-2). Catalysts [O1I] $\left(\mathrm{CuI}_{2}\right)$ showed higher activity in the hydroxylation reaction when oxygenated C1a.CuI was used. Therefore, this bis $(\mu-$ oxido) species was evaluated hereinafter towards other substrate classes. When copper iodide was oxygenated without a supporting ligand system, only a very small amount of 2-naphthol was converted, only leading to traces of $\mathbf{P 1}$ as expected (Sect. 5.3 in the Supporting Information).

3 -quinolinol was fully converted by $[\mathbf{O 1 I}]\left(\mathrm{CuI}_{2}\right)$ within three hours at room temperature to give quinolino[3,4-b] quinoxaline (P2) after condensation with 1,2-phenylenediamine (entry 3). $\mathbf{P 2}$ was purified by column chromatography as well as by sublimation and isolated in 56\% yield. Similarly, 6-quinolinol was transformed quantitatively to afford pyrido[3,2-a]phenazine (P3) in 61\% isolated yield (entry 4). $\mathrm{C}-\mathrm{H}$ functionalization of the pyrrole ring of indolols were achieved by $[\mathbf{O 1 I}]\left(\mathrm{CuI}_{2}\right)$ leading to pyrrolophenazines $\mathbf{P 4}$ and $\mathbf{P 5}$ in $41-58 \%$ yield (entries 5-6). An increase of the hydroxylation reaction time to $12 \mathrm{~h}$ did not lead to undesired side reactions, underlining the high selectivity in the oxygenation reaction mediated by bis( $\mu$-oxido) complex [O1I] $\left(\mathrm{CuI}_{2}\right)$. In comparison to our previously reported system $[\mathbf{O 1}]\left(\mathrm{PF}_{6}\right)_{2}$, bis $\left(\mu\right.$-oxido) species $[\mathbf{O 1 I}]\left(\mathrm{CuI}_{2}\right)$ revealed an overall higher activity in hydroxylation reactions. The additional steric demand of the iodide bridge between the copper centers depicted no influence on the $\mathrm{Cu}_{2} \mathrm{O}_{2}$ core accessibility towards exogenous substrates. Instead, the achieved room temperature stability of $[\mathbf{O 1 I}]\left(\mathrm{CuI}_{2}\right)$ enhances the activity of the catalyst. As a result, the accessibility of the reactive center from one direction appears to be sufficient to successfully perform catalytic oxygenation reactions.
The observed high reactivity of the bis( $\mu$-oxido) species poses the question, how this formal "oxido" species can exert an electrophilic hydroxylation reactivity. The concept of the inverted ligand field [82] helps to explain this apparent contradiction: the bis( $\mu$-oxido) species possesses electron holes on the formal bis( $\mu$-oxido) moieties since LUMO and LUMO +1 have large oxygen p character (see Fig. 6 and Ref. [82]). Besides, another question points to the bridging iodide which "survives" the close proximity to two $\mathrm{Cu}$ (III) centers, or at least an oxidative species. We relate this stability to the diminished outer-sphere oxidative ability of $[\mathbf{O 1}]^{2+}$ and $[\mathbf{O 1 I}]^{+}$since we did never observe $\mathrm{C}-\mathrm{C}$ coupling products. Under these circumstances, we propose that $\mathrm{I}_{2}$ cannot be formed.

\section{Conclusion}

In conclusion, we presented the synthesis and characterization of a bis( $\mu$-oxido) dicopper(III) iodidocuprate species, which was stabilized by the hybrid guanidine ligand L1. The bis( $\mu$-oxido) complex exhibited surprisingly high stability at room temperature. Titration experiments of the bis( $\mu$-oxido) species indicated the formation of iodidocuprate anions which were also found in cryo-UHR-ESI measurements.

The bis( $\mu$-oxido) system showed its great flexibility with respect to its stability and spectroscopic features, providing a toolbox for tailored dioxygen transfer reactions. A simple salt metathesis from weakly coordinating anions to coordinating anions caused a wavelength shift of the bis( $\mu$-oxido) complex and allowed a great leap in stability from $-90{ }^{\circ} \mathrm{C}$ to room temperature, underlining the influence of an additional halide ligand on the bis( $\mu$-oxido) dicopper(III) core. Even in a competitive oxygenation reaction, the more stable bis( $\mu$-oxido) species was formed. In addition, compound $[\mathbf{O 1 I}]\left(\mathrm{CuI}_{2}\right)$ revealed a higher activity in $\mathrm{C}-\mathrm{H}$ functionalization reactions towards different classes of polycyclic aromatic alcohols than its relative $[\mathbf{O 1}]\left(\mathrm{PF}_{6}\right)_{2}$. Resulting quinones were directly transformed into their stable phenazine form and were isolated in good yield. Achieved mild reaction conditions in a catalytic one-pot reaction pave the way for future transformation reactions applied on a larger scale on the route to industrial applications.

Supplementary Information The online version contains supplementary material available at https://doi.org/10.1007/s00775-021-01849-9.

Acknowledgements The authors gratefully acknowledge the financial support provided by the German Research Foundation (DFG), in framework of the Priority Program "Reactive Bubbly Flows" SPP 1740 (HE 5480/10-2, http://www.dfg-spp1740.de/). We furthermore thank the Paderborn Center for Parallel Computing, $\mathrm{PC}^{2}$, for providing 
computing time on the High-Performance Computing (HPC) system OCuLUS as well as support.

Funding Open Access funding enabled and organized by Projekt DEAL.

\section{Compliance with ethical standards}

Conflict of interest The authors declare no conflict of interest.

Open Access This article is licensed under a Creative Commons Attribution 4.0 International License, which permits use, sharing, adaptation, distribution and reproduction in any medium or format, as long as you give appropriate credit to the original author(s) and the source, provide a link to the Creative Commons licence, and indicate if changes were made. The images or other third party material in this article are included in the article's Creative Commons licence, unless indicated otherwise in a credit line to the material. If material is not included in the article's Creative Commons licence and your intended use is not permitted by statutory regulation or exceeds the permitted use, you will need to obtain permission directly from the copyright holder. To view a copy of this licence, visit http://creativecommons.org/licenses/by/4.0/.

\section{References}

1. Gray HB, Winkler JR (2018) Acc Chem Res 51:1850-1857

2. Campbell AN, Stahl SS (2012) Acc Chem Res 45:851-863

3. McCann SD, Stahl SS (2015) Acc Chem Res 48:1756-1766

4. Solomon EI, Heppner DE, Johnston EM, Ginsbach JW, Cirera J, Qayyum M, Kieber-Emmons MT, Kjaergaard CH, Hadt RG, Tian L (2014) Chem Rev 114:3659-3853

5. Elwell CE, Gagnon NL, Neisen BD, Dhar D, Spaeth AD, Yee GM, Tolman WB (2017) Chem Rev 117:2059-2107

6. Mirica LM, Ottenwaelder X, Stack TDP (2004) Chem Rev 104:1013-1046

7. Bijelic A, Pretzler M, Molitor C, Zekiri F, Rompel A (2015) Angew Chem Int Ed 54:14677-14680

8. Kahn V, Ben-Shalom N (1998) Pigment Cell Res 11:24-33

9. del Garcia-Molina M, Muñoz-Muñoz JL, Garcia-Molina F, García-Ruiz PA, Garcia-Canovas F (2012) J Agric Food Chem 60:6447-6453

10. Liebhäuser P, Hoffmann A, Herres-Pawlis S (2019) Ref Modul Chem Mol Sci Chem Eng. 1-22

11. Hamann JN, Herzigkeit B, Jurgeleit R, Tuczek F (2017) Coord Chem Rev 334:54-66

12. Réglier M, Jorand C, Waegell B (1990) J Chem Soc, Chem Commun. 1752-1755.

13. Casella L, Gullotti M, Radaelli R, Di Gennaro P (1991) J Chem Soc, Chem Commun. 1611-1612

14. Esguerra KVN, Fall Y, Lumb JP (2014) Angew Chem Int Ed 53:5877-5881

15. Askari MS, Rodríguez-Solano LA, Proppe A, McAllister B, Lumb J-P, Ottenwaelder X (2015) Dalton Trans 44:12094-12097

16. Huang Z, Kwon O, Huang H, Fadli A, Marat X, Moreau M, Lumb JP (2018) Angew Chem Int Ed 57:11963-11967

17. Rolff M, Schottenheim J, Peters G, Tuczek F (2010) Angew Chem Int Ed 49:6438-6442

18. Schottenheim J, Fateeva N, Thimm W, Krahmer J, Tuczek F (2013) Z Anorg Allg Chem 639:1491-1497

19. Hamann JN, Tuczek F (2014) Chem Commun 50:2298-2300
20. Hamann JN, Schneider R, Tuczek F (2015) J Coord Chem 68:3259-3271

21. Wendt F, Näther C, Tuczek F (2016) J Biol Inorg Chem 21:777-792

22. Herzigkeit B, Flöser BM, Engesser TA, Näther C, Tuczek F (2018) Eur J Inorg Chem 2018:3058-3069

23. Herzigkeit B, Flöser BM, Meißner NE, Engesser TA, Tuczek F (2018) ChemCatChem 10:5402-5405

24. Herzigkeit B, Jurgeleit R, Flöser BM, Meißner NE, Engesser TA, Näther C, Tuczek F (2019) Eur J Inorg Chem 2019:2258-2266

25. Hoffmann A, Citek C, Binder S, Goos A, Rübhausen M, Troeppner O, Ivanović-Burmazović I, Wasinger EC, Stack TDP, HerresPawlis S (2013) Angew Chem Int Ed 52:5398-5401

26. Wilfer C, Liebhäuser P, Hoffmann A, Erdmann H, Grossmann O, Runtsch L, Paffenholz E, Schepper R, Dick R, Bauer M, Dürr M, Ivanovic-Burmazovic I, Herres-Pawlis S (2015) Chem Eur J 21:17639-17649

27. Wilfer C, Liebhäuser P, Erdmann H, Hoffmann A, Herres-Pawlis S (2015) Eur J Inorg Chem 2015:494-502

28. Liebhäuser P, Keisers K, Hoffmann A, Schnappinger T, Sommer I, Thoma A, Wilfer C, Schoch R, Stührenberg K, Bauer M, Dürr M, Ivanović-Burmazović I, Herres-Pawlis S (2017) Chem Eur J 23:12171-12183

29. Strassl F, Hoffmann A, Grimm-Lebsanft B, Rukser D, Biebl F, Tran M, Metz F, Rübhausen M, Herres-Pawlis S (2018) Inorganics 6:114-136

30. Herres-Pawlis S, Binder S, Eich A, Haase R, Schulz B, Wellenreuther G, Henkel G, Rübhausen M, Meyer-Klaucke W (2009) Chem Eur J 15:8678-8682

31. Herres-Pawlis S, Verma P, Haase R, Kang P, Lyons CT, Wasinger EC, Flörke U, Henkel G, Stack TDP (2009) J Am Chem Soc 131:1154-1169

32. Herres-Pawlis S, Haase R, Verma P, Hoffmann A, Kang P, Stack TDP (2015) Eur J Inorg Chem 2015:5426-5436

33. Schurr D, Strassl F, Liebhäuser P, Rinke G, Dittmeyer R, HerresPawlis S (2016) React Chem Eng 1:485-493

34. Strassl F, Grimm-Lebsanft B, Rukser D, Biebl F, Biednov M, Brett C, Timmermann R, Metz F, Hoffmann A, Rübhausen M, Herres-Pawlis S (2017) Eur J Inorg Chem 2017:3350-3359

35. Paul M, Strassl F, Hoffmann A, Hoffmann M, Schlüter M, HerresPawlis S (2018) Eur J Inorg Chem 2018:2101-2124

36. Schön F, Biebl F, Greb L, Leingang S, Grimm-Lebsanft B, Teubner M, Buchenau S, Kaifer E, Rübhausen MA, Himmel H (2019) Chem Eur J 25:11257-11268

37. Schatz M, Raab V, Foxon SP, Brehm G, Schneider S, Reiher M, Holthausen MC, Sundermeyer J, Schindler S (2004) Angew Chem Int Ed 43:4360-4363

38. Maiti D, Lee D-H, Gaoutchenova K, Würtele C, Holthausen MC, Narducci Sarjeant AA, Sundermeyer J, Schindler S, Karlin KD (2008) Angew Chem Int Ed 47:82-85

39. Herres S, Heuwing AJ, Flörke U, Schneider J, Henkel G (2005) Inorg Chim Acta 358:1089-1095

40. Paul M, Teubner M, Grimm-Lebsanft B, Golchert C, Meiners Y, Senft L, Keisers K, Liebhäuser P, Rösener T, Biebl F, Buchenau S, Naumova M, Murzin V, Krug R, Hoffmann A, Pietruszka J, Ivanović-Burmazović I, Rübhausen M, Herres-Pawlis S (2020) Chem Eur J 26:7556-7562

41. Cross B, Dunn CL, Payne DH, Tipton JD (1969) J Sci Food Agric 20:340-344

42. Guttenberger N, Blankenfeldt W, Breinbauer R (2017) Bioorg Med Chem 25:6149-6166

43. de Andrade-Neto VF, Goulart MOF, da Silva Filho JF, da Silva MJ, do Carmo FR, Pinto M, Pinto AV, Zalis MG, Carvalho LH, Krettli AU (2004) Bioorg Med Chem Lett 14:1145-1149

44. Mortzfeld FB, Pietruszka J, Baxendale IR (2019) Eur J Org Chem 2019:5424-5433 
45. Chaudhary A, Khurana JM (2018) Res Chem Intermed 44:1045-1083

46. Xiao Y, Hu W, Sun S, Yu J-T, Cheng J (2019) Synlett 30:2113-2122

47. Bilal M, Guo S, Iqbal HMN, Hu H, Wang W, Zhang X (2017) World J Microbiol Biotechnol 33:191

48. Cimmino A, Evidente A, Mathieu V, Andolfi A, Lefranc F, Kornienko A, Kiss R (2012) Nat Prod Rep 29:487-501

49. Kubas GJ, Monzyk B, Crumbliss AL (1979) Inorg Synth 19:90-92

50. Hardt H-D (1959) Z Anorg Allg Chem 301:87-96

51. Stoe \& Cie GmbH (2017) X-Area Pilatus3_SV 1.31.131.0, Darmstadt, Germany

52. Stoe \& Cie GmbH (2015) X-Area Recipe 1.33.0.0, Darmstadt, Germany

53. Stoe \& Cie GmbH (2016) X-Area Integrate 1.71.0.0, Darmstadt, Germany

54. Stoe \& Cie GmbH (2017) X-Area LANA 1.71.4.0, Darmstadt, Germany.

55. Bruker AXS Inc. (1997) X-PREP 5.1, Madison, Wisconsin, USA.

56. Sheldrick GM (2015) Acta Crystallogr Sect A 71:3-8

57. Sheldrick GM (2015) Acta Crystallogr Sect C 71:3-8

58. Hübschle CB, Sheldrick GM, Dittrich B (2011) J Appl Crystallogr 44:1281-1284

59. Frisch MJ, Trucks GW, Schlegel HB, Scuseria GE, Robb MA, Cheeseman JR, Scalmani G, Barone V, Petersson GA, Nakatsuji H, Li X, Caricato M, Marenich AV, Bloino J, Janesko BG, Gomperts R, Mennucci B, Hratchian HP, Ortiz JV, Izmaylov AF, Sonnenberg JL, Williams-Young D, Ding F, Lipparini F, Egidi F, Goings J, Peng B, Petrone A, Henderson T, Ranasinghe D, Zakrzewski VG, Gao J, Rega N, Zheng G, Liang W, Hada M, Ehara M, Toyota K, Fukuda R, Hasegawa J, Ishida M, Nakajima T, Honda Y, Kitao O, Nakai H, Vreven T, Throssell K, Montgomery JA Jr., Peralta JE, Ogliaro F, Bearpark MJ, Heyd JJ, Brothers EN, Kudin KN, Staroverov VN, Keith TA, Kobayashi R, Normand J, Raghavachari K, Rendell AK, Burant JC, Iyengar SS, Tomasi J, Cossi M, Millam JM, Klene M, Adamo C, Cammi R, Ochterski JW, Martin RL, Morokuma K, Farkas O, Foresman JB, Fox DJ, Gaussian, Inc. (2016), Gaussian 16, Revision B.01, Wallingford CT, USA.

60. Tao J, Perdew JP, Staroverov VN, Scuseria GE (2003) Phys Rev Lett 91:146401

61. Staroverov VN, Scuseria GE, Tao J, Perdew JP (2003) J Chem Phys 119:12129-12137

62. Staroverov VN, Scuseria GE, Tao J, Perdew JP (2004) J Chem Phys 121:11507

63. Weigend F, Ahlrichs R (2005) Phys Chem Chem Phys 7:3297-3305
64. Schäfer A, Huber C, Ahlrichs R (1994) J Chem Phys 100:5829-5835

65. Eichkorn K, Weigend F, Treutler O, Ahlrichs R (1997) Theor Chem Accounts Theory Comput Model 97:119-124

66. Weigend F, Häser M, Patzelt H, Ahlrichs R (1998) Chem Phys Lett 294:143-152

67. Peterson KA, Figgen D, Goll E, Stoll H, Dolg M (2003) J Chem Phys 119:11113-11123

68. Baldes A, Turbomole basis set library II. https://cosmologic-servi ces.de/basis-sets/basissets.php Accessed 22 December 2019

69. Grimme S, Ehrlich S, Goerigk L (2011) J Comput Chem 32:1456-1465

70. Goerigk L, Grimme S (2011) Phys Chem Chem Phys 13:6670

71. For TPSSh, the values of the original paper have been substituted by the corrected values kindly provided by S. Grimme as private communication and published in [72].

72. Hoffmann A, Grunzke R, Herres-Pawlis S (2014) J Comput Chem 35:1943-1950

73. Hussain H, Specht S, Sarite SR, Saeftel M, Hoerauf A, Schulz B, Krohn K (2011) J Med Chem 54:4913-4917

74. Bienemann O, Haase R, Jesser A, Beschnitt T, Döring A, Kuckling D, dos Santos VI, Flörke U, Herres-Pawlis S (2011) Eur J Inorg Chem 2011:2367-2379

75. Raab V, Harms K, Sundermeyer J, Kovacević B, Maksić ZB (2003) J Org Chem 68:8790-8797

76. Hoyer M, Hartl H (1991) Z Anorg Allg Chem 598:151-162

77. Hoyer M, Hartl H (1992) Z Anorg Allg Chem 612:45-50

78. Wheaton AM, Streep ME, Ohlhaver CM, Nicholas AD, Barnes FH, Patterson HH, Pike RD (2018) ACS Omega 3:15281-15292

79. Rohrmüller M, Hoffmann A, Thierfelder C, Herres-Pawlis S, Schmidt WG (2015) J Comput Chem 36:1672-1685

80. Hamann JN, Rolff M, Tuczek F (2015) Dalton Trans 44:3251-3258

81. Bulkowski JE (1985) Binucleating Ligand-Metal Complexes as Oxidation Catalysts, US Patent 4,545,937.

82. DiMucci IM, Lukens JT, Chatterjee S, Carsch KM, Titus CJ, Lee SJ, Nordlund D, Betley TA, MacMillan SN, Lancaster KM (2019) J Am Chem Soc 141:18508-18520

Publisher's Note Springer Nature remains neutral with regard to jurisdictional claims in published maps and institutional affiliations. 